\title{
Final Report: \\ Monitoring Well Installation \\ and Sampling, 2004, at Morrill, Kansas
}

prepared by

Environmental Research Division

Argonne National Laboratory
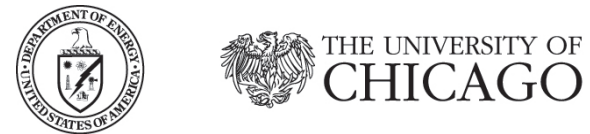

Argonne National Laboratory is managed by The University of Chicago for the U.S. Department of Energy

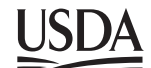


About Argonne National Laboratory

Argonne is a U.S. Department of Energy laboratory managed by The University of Chicago

under contract W-31-109-Eng-38. The Laboratory's main facility is outside Chicago, at

9700 South Cass Avenue, Argonne, Illinois 60439. For information about Argonne,

see www.anl.gov.

\section{Availability of This Report}

This report is available, at no cost, at http://www.osti.gov/bridge. It is also available

on paper to the U.S. Department of Energy and its contractors, for a processing fee, from:

U.S. Department of Energy

Office of Scientific and Technical Information

P.O. Box 62

Oak Ridge, TN 37831-0062

phone (865) 576-8401

fax (865) 576-5728

reports@adonis.osti.gov

\section{Disclaimer}

This report was prepared as an account of work sponsored by an agency of the United States Government. Neither the United States Government nor any agency thereof, nor The University of Chicago, nor any of their employees or officers, makes any warranty, express or implied, or assumes any legal liability or responsibility for the accuracy, completeness, or usefulness of any information, apparatus, product, or process disclosed, or represents that its use would not infringe privately owned rights. Reference herein to any specific commercial product, process, or service by trade name, trademark, manufacturer, or otherwise, does not necessarily constitute or imply its endorsement, recommendation, or favoring by the United States Government or any agency thereof. The views and opinions of document authors expressed herein do not necessarily state or reflect those of the United States Government or any agency thereof, Argonne National Laboratory, or The University of Chicago. 


\section{Final Report:}

Monitoring Well Installation and Sampling, 2004, at Morrill, Kansas

by

Applied Geosciences and Environmental Management Section

Environmental Research Division, Argonne National Laboratory

November 2005 


\section{Contents}

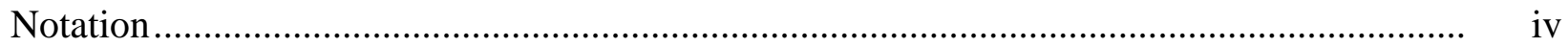

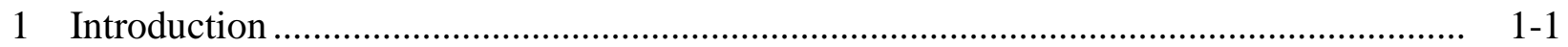

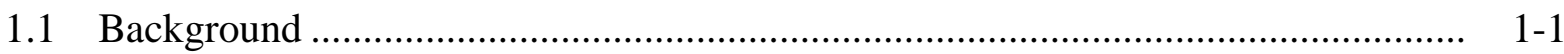

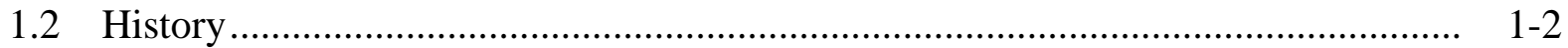

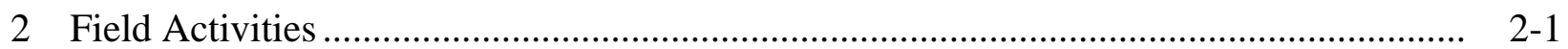

$2.1 \quad$ Installation of Monitoring Wells ......................................................................... 2-1

2.2 Sampling of Monitoring Wells......................................................................... 2-2

2.3 Sampling of Private Wells................................................................................... 2-3

2.4 Quality Control for Sample Collection, Handling, and Analysis.............................. 2-4

3 Field and Laboratory Data.....................................................................................

3.1 Coordinates Survey Data................................................................................... 3-1

3.2 Analytical Data for Groundwater..................................................................... 3-1

3.2.1 Field Measurements ........................................................................ 3-1

3.2.2 Contaminant Data.................................................................................. $3-1$

3.2.3 Major Elements ........................................................................ 3-2

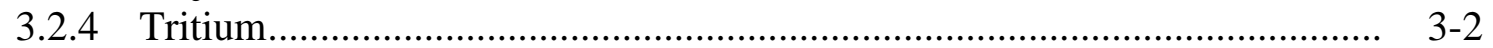

3.3 Groundwater Level Data ........................................................................... 3-2

3.4 Results of Quality Control Activities .................................................................... 3-3

4 Interpretation of Field and Laboratory Data ………..................................................... 4-1

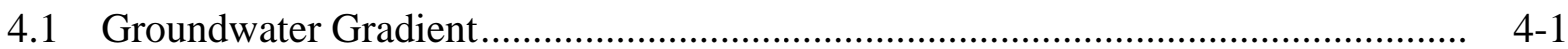

4.2 Delineation of the Groundwater Plume................................................................... 4-1

4.3 Site Conceptual Model ................................................................................... 4- 4

5 Conclusions and Recommendations............................................................................. $5-1$

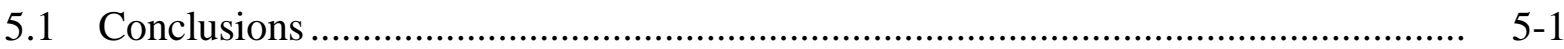

5.2 Recommendations ...................................................................................... $5-2$

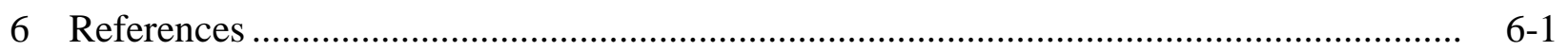

Appendix A： Well Construction Diagrams ..................................................................... A-1

Appendix B: Coordinates Survey Data....................................................................... B-1

Appendix C: Groundwater Sample Data …………………………………………....... C-1

Appendix D: Water Level Data ……………………….................................................. D-1

Appendix E: Quality Control for Sample Collection, Handling, and Analysis..................... E-1 


\section{Table}

2.1 Construction details for monitoring wells MW6S-MW8S at Morrill, Kansas

\section{Figures}

1.1 Location of Brown County and Morrill, Kansas ............................................... 1-3

1.2 Locations of the former CCC/USDA grain storage facility and public wells at Morrill

2.1 Locations of the KDHE monitoring wells and the three new monitoring wells, MW6S, MW7S, and MW8S, installed in May 2004

2.2 Locations of the 10 private wells identified as being within or near the plume and within $1 \mathrm{mi}$ downgradient of the former CCC/USDA facility

3.1 Carbon tetrachloride and chloroform concentrations in groundwater at Morrill, 2004

3.2 Nitrate concentrations in groundwater at Morrill, 2004.

4.1 The potentiometric surface of the upper aquifer in the investigation area at Morrill, as measured manually on July 15, 2004, and in October 2003.

4.2 Local groundwater elevation contours at Morrill in 1995 and 1994.

4.3 Distribution of carbon tetrachloride in groundwater at Morrill, on the basis of 2004 sampling results.

4.4 Location of interpretive south-north cross section B-B" in the investigation area at Morrill

4.5 Inferred contaminant migration pathway at the former CCC/USDA facility at Morrill, displayed on interpretive geologic cross section B-B" 


\section{Notation}

AGEM

AMSL

BGL

${ }^{\circ} \mathrm{C}$

$\mathrm{CCC}$

CLP

$\mathrm{COC}$

DOE

EPA

$\mathrm{ft}$

gal

GC-MS

gpm

ICP

in.

KDHE

MCL

$\mu \mathrm{g} / \mathrm{L}$

$\mathrm{mg} / \mathrm{L}$

mi

$\mu \mathrm{S} / \mathrm{cm}$

NAD

NGVD

PVC

QA

QC

RPD

SDG

TOC

TU

USDA

VOC
Applied Geosciences and Environmental Management

above mean sea level

below ground level

degrees Celsius

Commodity Credit Corporation

Contract Laboratory Program

chain of custody

U.S. Department of Energy

U.S. Environmental Protection Agency

foot (feet)

gallon(s)

gas chromatograph-mass spectrometer

gallon(s) per minute

inductively coupled plasma

inch(es)

Kansas Department of Health and Environment

maximum contaminant level

microgram(s) per liter

milligram(s) per liter

mile(s)

microsiemen(s) per centimeter

North American Datum

National Geodetic Vertical Datum

polyvinyl chloride

quality assurance

quality control

relative percent difference

sample delivery group

top of casing

tritium unit(s)

U.S. Department of Agriculture

volatile organic compound 


\section{Final Report: Monitoring Well Installation and Sampling, 2004, Morrill, Kansas}

\section{Introduction}

\subsection{Background}

This report documents the activities associated with the installation in 2004 of three groundwater monitoring wells at Morrill, Kansas, and the subsequent sampling of these wells and the six existing Kansas Department of Health and Environment (KDHE) monitoring wells. Also sampled were known private wells located within and downgradient of an area of groundwater contaminated with carbon tetrachloride. These activities were conducted as part of an ongoing environmental investigation at Morrill that is being performed by the Environmental Research Division of Argonne National Laboratory. Argonne is a nonprofit, multidisciplinary research center operated by the University of Chicago for the U.S. Department of Energy (DOE). The Commodity Credit Corporation (CCC), an agency of the U.S. Department of Agriculture (USDA), has entered into an interagency agreement with DOE, under which Argonne provides technical assistance to the CCC/USDA with environmental site characterization and remediation at its former grain storage facilities.

The need for three additional monitoring wells at Morrill to supplement the existing sixwell network initially installed by the KDHE (GeoCore 1996) was documented in a letter report (Argonne 2003a), based on the data collected in October 2003, during the Phase I-Phase II expedited site characterization (Argonne 2004a). In December 2003, following approval of the proposed locations by the KDHE, a work plan for the installation and sampling of the monitoring wells was prepared and submitted to the KDHE (Argonne 2004b). This work plan, together with subsequent modifications (Argonne 2004c), was approved by the KDHE on April 8, 2004.

Field work associated with the installation of the three monitoring wells was conducted in May 2004. Sampling of the existing monitoring wells and the known private wells within and downgradient of an area of groundwater contaminated with carbon tetrachloride occurred in June 2004. For one private well, permission to sample was denied. One private well at the co-op was sampled in February 2004, and one private well identified after June 2004 was sampled in August 2004. 
The results of these activities, together with the data and findings reported in the Phase IPhase II Interim Report (Argonne 2004a), complete the scope of work presented in the Phase I Work Plan (Argonne 2003b).

\subsection{History}

The city of Morrill, Kansas, is located in Brown County, in the northeastern corner of the state (Figure 1.1). The town lies about $7 \mathrm{mi}$ east of Sabetha and about $10 \mathrm{mi}$ northwest of Hiawatha. The population of Morrill as of the 2000 census was approximately 277.

From 1950 until 1971, the CCC/USDA operated a grain storage facility in the northwestern section of Morrill (Figure 1.2). Fourteen of the CCC/USDA circular bin structures remain. Prior to 1986, commercial grain fumigants containing carbon tetrachloride were commonly used by the CCC/USDA and the grain storage industry to preserve grain.

Contamination with carbon tetrachloride was initially identified in groundwater at Morrill in October 1985 in public water supply well PWS5 (Figure 1.2), during statewide testing of public water supply wells for volatile organic compounds (VOCs). A preliminary assessment was completed by the KDHE in 1989 to obtain background information on the Morrill public water supply and to identify potential sources of the detected carbon tetrachloride contamination (KDHE 1989).

Since 1991, the city of Morrill has obtained its water by pipeline from the municipal water supply of Sabetha. Water supplied through the Sabetha system comes from a surface reservoir. Former public wells in Morrill are no longer used for municipal supply. Public supply wells PWS3, PWS4, and PWS5 were plugged in 1993. Wells PWS1 and PWS2 are no longer in active production, but they continue to be available for nondrinking purposes such as bulk hauling for agricultural uses, fire fighting, and road work (Hansen 2001).

The CCC/USDA is conducting an environmental site investigation at Morrill because of carbon tetrachloride detected in the groundwater at the former CCC/USDA facility that could, in part, be linked to historical use of carbon tetrachloride-based grain fumigants at the facility. 


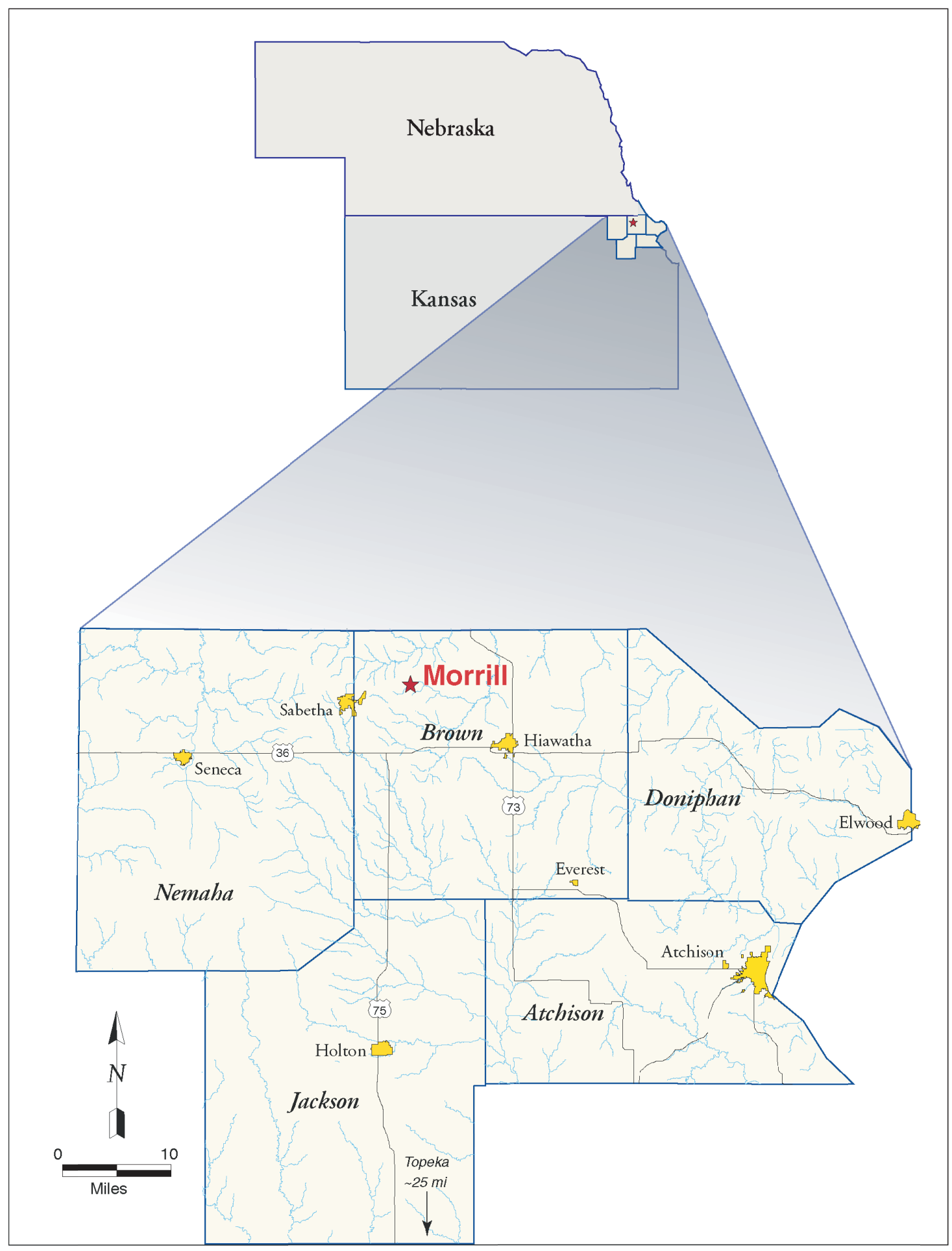

FIGURE 1.1 Location of Brown County and Morrill, Kansas. 


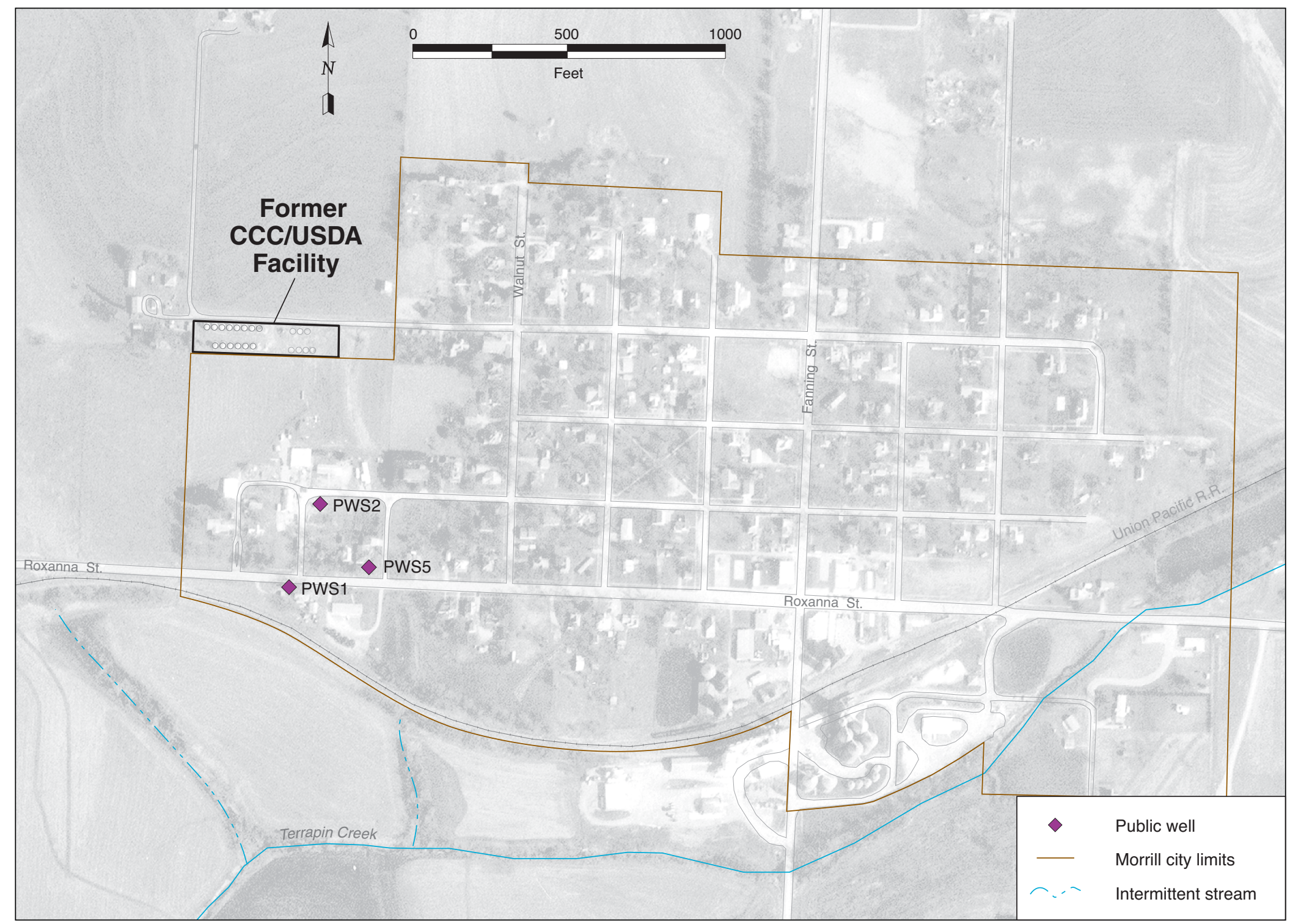

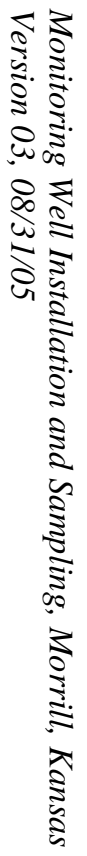

FIGURE 1.2 Locations of the former CCC/USDA grain storage facility and public wells at Morrill. Contamination was first detected at PWS5 in 1985. (Source of aerial photograph: USDA 1999.) 


\section{Field Activities}

\subsection{Installation of Monitoring Wells}

Three monitoring wells, MW6S, MW7S, and MW8S, were installed in May 2004 at the locations shown in Figure 2.1. Well MW6S was installed south-southeast of the known area of contamination along Terrapin Creek to help delineate the downgradient extent of the plume. Well MW7S was situated just north of Roxanna Street to help delineate the western lateral extent of the plume. Well MW8S is located southwest of well MW1S to delineate the southwestern portion of the plume.

The three monitoring wells were installed according to the general procedures presented in Section 6.4.3 of the Master Work Plan (Argonne 2002) and approved by the KDHE. Prior to installation of the wells, a ground elevation survey was conducted to confirm the ground elevation at each of the proposed locations. The total depths and screen lengths for MW6S, MW7S, and MW8S were adjusted to ensure that

- The groundwater monitoring data collected from these wells were comparable to data collected from the current KDHE-installed monitoring well network,

- The screen intervals were representative of the same general thickness of the aquifer zone as is sampled in the existing KDHE wells, and

- The samples were not subject to possible diluting effects that could result from sampling large, saturated screened intervals (Argonne 2004c).

The wells were constructed to enable sampling of the upper part of the aquifer zone from the water table to a depth no greater than approximately 1,060-1,065 ft AMSL (above mean sea level). The wells were constructed with 4-in. polyvinyl chloride (PVC) casing installed in 8 -in.-diameter boreholes. The boreholes were drilled by using an air rotary drill rig. Screens consist of 0.020 -slot screen with a no. 8 sand filter pack. The construction at the base of each well consists of a 2 -ft section of blank casing to serve as a silt trap. Screen lengths vary depending on the depth to groundwater at each location. Well construction details are in Table 2.1. 
TABLE 2.1 Construction details for monitoring wells MW6S-MW8S at Morrill, Kansas.

\begin{tabular}{|c|c|c|c|c|c|}
\hline \multirow[b]{3}{*}{ Well } & \multirow{3}{*}{$\begin{array}{c}\text { Surveyed } \\
\text { Surface Elevation } \\
\text { (ft AMSL) }\end{array}$} & \multicolumn{4}{|c|}{ Depth } \\
\hline & & \multirow{2}{*}{$\begin{array}{c}\text { To } \\
\text { Groundwater } \\
\left.\text { (ft BGL, estimated }{ }^{b}\right)\end{array}$} & \multicolumn{2}{|c|}{ Screen Intervalc } & \multirow{2}{*}{$\begin{array}{l}\text { Total Depthc } \\
\text { (ft BGL) }\end{array}$} \\
\hline & & & $\mathrm{ft} \mathrm{BGL}$ & ft AMSL & \\
\hline MW6S & 1,091 & $5-15$ & $10-25$ & $1,081-1,066$ & 27 \\
\hline MW7S & 1,120 & $25-35$ & $20-45$ & $1,100-1,075$ & 47 \\
\hline MW8S & 1,099 & $5-15$ & $10-25$ & $1,089-1,074$ & 27 \\
\hline
\end{tabular}

a Rounded to the nearest foot.

b Based on October 2003 groundwater levels.

c Screen interval and total depth were adjusted for aquifer thickness at each well location to ensure that these new wells sample the same general thickness of the aquifer zone as do the existing KDHE wells (Argonne 2004c).

All wells were constructed in accordance with applicable KDHE guidelines. Per agreement with the KDHE, well depths and screen intervals were adjusted in the field on the basis of differences between the surface elevations approximated from available topographic maps and the actual elevations surveyed prior to well installation. These adjustments resulted in reductions of screen lengths from the proposed $20 \mathrm{ft}$ to $15 \mathrm{ft}$ in MW6S and from the proposed $25 \mathrm{ft}$ to $15 \mathrm{ft}$ in MW8S. The changes enabled access to the same stratigraphic intervals as are screened and sampled in the KDHE monitoring wells (Gotto 2004; Surgnier 2004).

Per agreement with the KDHE, waste generated during the installation of the wells in 2004 was disposed on-site. Development water was discharged at each drilling location, and the drill cuttings were scarified at each site. Surface completions consist of KDHE-approved flush mounts, as shown in the specifications for a 4-in. casing in Figure F.4, Appendix F, of the Master Work Plan (Argonne 2002). Completion diagrams and well registration forms for wells MW6SMW8S are in Appendix A of this report.

\subsection{Sampling of Monitoring Wells}

Following installation and development of the three new monitoring wells in May 2004, groundwater samples were collected and analyzed for anions and cations to establish a reference data set to be used to gauge the effectiveness of the initial well development. Approximately four weeks after installation, in June 2004, the three new monitoring wells (MW6S-MW8S) and the 
six existing KDHE monitoring wells (MW1D and MW1S-MW5S) were purged and sampled. All wells were sampled in accordance with procedures in the Master Work Plan (Argonne 2002), Section 6.1.2.4, as follows:

- The wells were purged of at least three well volumes.

- Samples were taken after stabilization of field parameters.

- Samples were collected with a Teflon-lined sampling hose or with a bailer.

Purge water generated from wells MW1S, MW3S, and MW7S was placed in containers for proper disposal at an approved facility at Sabetha, Kansas. Purge water generated from the other six wells was discharged to the ground, as indicated in Section 6.1.5 of the Master Work Plan (Argonne 2002) and by prior agreement with the KDHE. Samples collected from the monitoring wells were analyzed for VOCs, anions, cations, nitrate, and tritium.

\subsection{Sampling of Private Wells}

Ten private wells were identified as within or near the plume footprint and within $1 \mathrm{mi}$ downgradient of the former CCC/USDA facility (Figure 2.2). Five of these wells are situated within the known extent of the plume. These are the Stone, Rilinger, Allen, Manning, and Cain/Stover wells; none of these wells is used for drinking water. The Cain/Stover well, identified during previous well surveys conducted by GeoCore (GeoCore 1994, 1996), was not sampled in 2004 because the property owner denied access. Four wells were identified as located downgradient of the plume: the Isch well (located at the co-op), the Snyder well (identified as the Avis Miller well in Figure 4.6 of the Phase I-II report [Argonne 2004a]), the Kent Grimm well, and the Rodney Grimm well. One additional well, the Moravec well, located upgradient and near the plume, was included in the 2004 sampling.

All but two of the private wells were sampled on June 2, 2004. The June 2 samples were analyzed for VOCs and for anions, cations, nitrate, and tritium. The Isch well was sampled for VOCs in February 2004, and the Allen well was sampled for VOCs in August 2004. Prior to sampling, each well was purged either by pumping or by letting water discharge from the associated spigot. 


\subsection{Quality Control for Sample Collection, Handling, and Analysis}

The quality assurance/quality control (QA/QC) procedures followed for sample collection, handling, and analysis are described in detail in the Master Work Plan (Argonne 2002). Significant points include the following:

- Sample integrity was preserved throughout the collection, shipping, and analysis activities by the use of custody seals and chain-of-custody records.

- Analytical results for a field blank, equipment rinsates, and trip blanks indicate that sample collection and handling procedures were followed and that carbon tetrachloride and chloroform contamination detected in the groundwater samples did not result from cross-contamination of the samples during collection or shipment. Likewise, analytical results for method blanks indicate that cross-contamination did not occur during analysis.

- Groundwater samples were analyzed for carbon tetrachloride and chloroform at the Applied Geosciences and Environmental Management (AGEM) Laboratory by using U.S. Environmental Protection Agency (EPA) Method 524.2. (The EPA methods are indexed online [http://www.epa.gov/epahome/index].) Replicate samples were sent to Envirosystems, Inc., Columbia, Maryland, for verification analyses with EPA Contract Laboratory Program (CLP) methodology. Low relative percent difference values between the primary samples and secondary QC samples indicate that good precision was achieved in the analyses. The organic analytical results are acceptable for delineation of the contaminant plume.

- Groundwater samples were analyzed for inorganic constituents at SevernTrent Laboratory in Colchester, Vermont. The analyses included dissolved anion concentrations (chloride, sulfate, nitrate, and phosphate) by EPA Method 300, nitrite nitrogen by EPA Method 354.1, nitrate/nitrite nitrogen by EPA Method 353.2, and dissolved metals (aluminum, calcium, iron, magnesium, manganese, phosphorus, potassium, silicon, sodium, and zinc) by EPA Method 6010. The inorganic results are acceptable for geochemical characterization on the basis of (1) the recovery of known concentrations of 
the analytes of concern in QC samples and (2) low relative percent difference values in duplicate analyses.

- Groundwater samples were analyzed for tritium at the University of Miami Tritium Laboratory in Miami, Florida. Good precision in the analyses is indicated by the low relative percent difference values achieved in duplicate analyses. The tritium analytical data are acceptable for age-dating of the groundwater. 


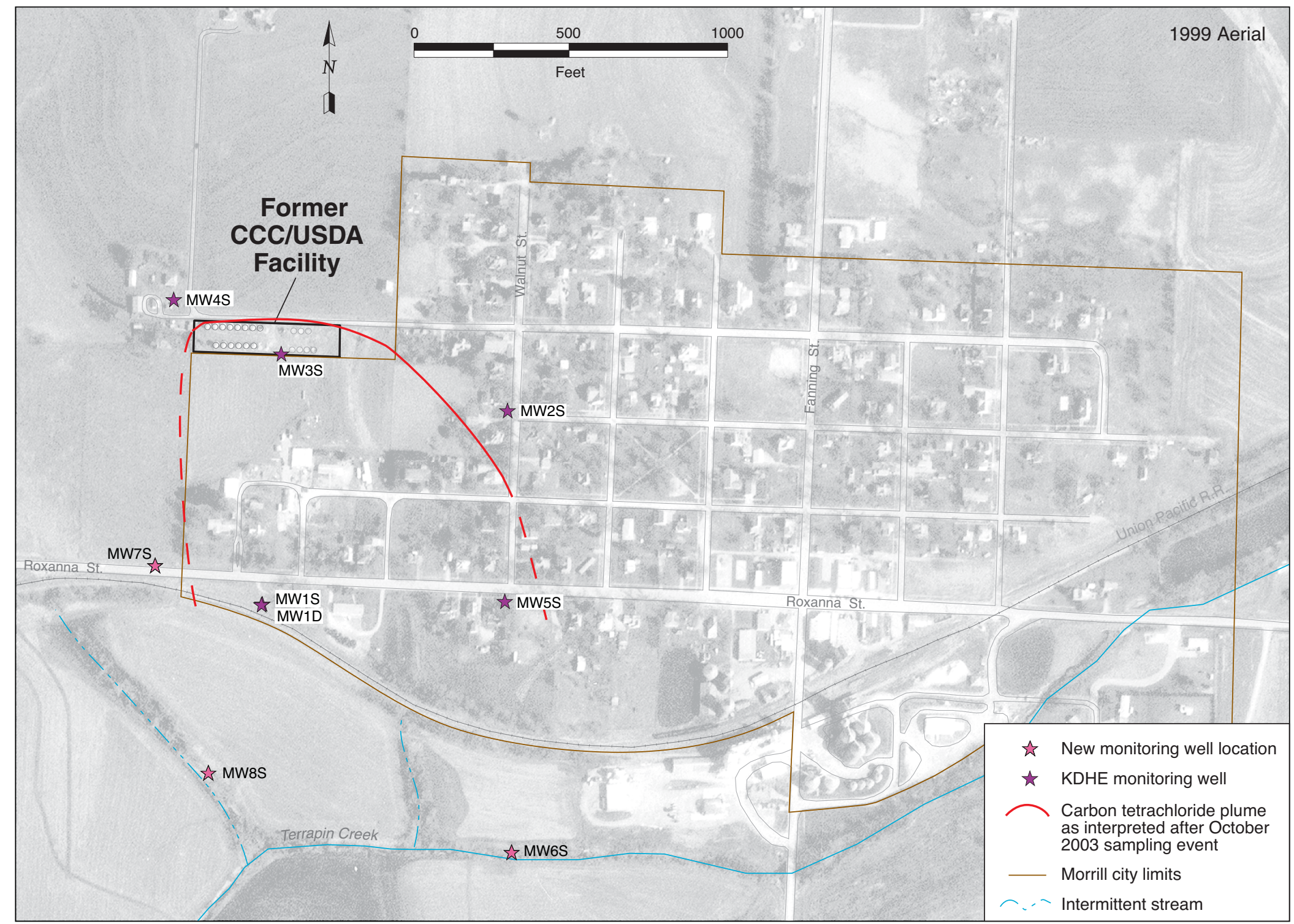

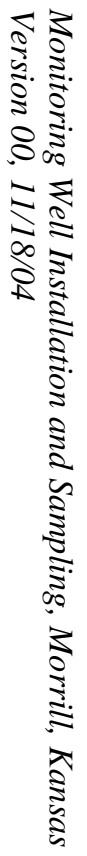

FIGURE 2.1 Locations of the KDHE monitoring wells and the three new monitoring wells, MW6S, MW7S, and MW8S, which were installed in May 2004. (Source of aerial photograph: USDA 1999.) 


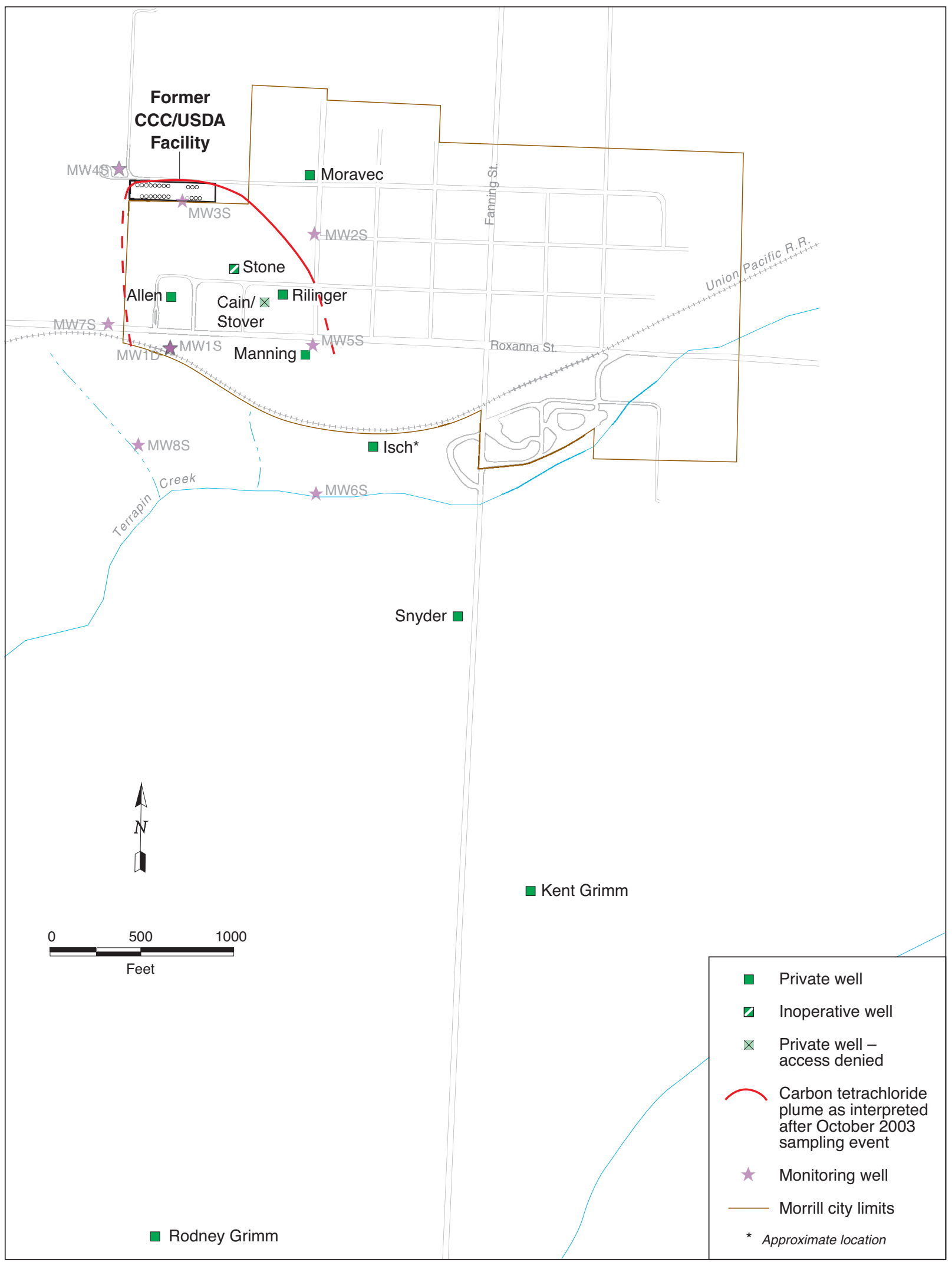

FIGURE 2.2 Locations of the 10 private wells identified as being within or near the plume and within $1 \mathrm{mi}$ downgradient of the former CCC/USDA facility. 


\section{Field and Laboratory Data}

\subsection{Coordinates Survey Data}

The three newly installed monitoring wells, MW6S-MW8S, were surveyed by SchwabEaton, P.A., Manhattan, Kansas, to provide horizontal and vertical control for water level monitoring. Both ground elevation and the top-of-casing elevation were surveyed. Coordinates survey data for all nine monitoring wells are in Appendix B, Table B.1.

\subsection{Analytical Data for Groundwater}

Groundwater samples were collected from the nine monitoring wells and the nine identified private wells. These samples were analyzed for VOCs by using EPA Method 524.2. If sufficient sample volume was available, the samples were also analyzed for anions, cations, and tritium. Descriptions of the groundwater samples are in Table C.1, Appendix C.

\subsubsection{Field Measurements}

Field measurements of temperature, $\mathrm{pH}$, and electrical conductivity were taken after well purging and stabilization of parameters. (Well MW2S was purged dry twice.) Results of field measurements for the monitoring wells are in Table C.2, Appendix C.

\subsubsection{Contaminant Data}

Carbon tetrachloride was detected above the quantitation limit $(1 \mu \mathrm{g} / \mathrm{L})$ and the maximum contaminant level (MCL; $5 \mu \mathrm{g} / \mathrm{L})$ in four of the nine monitoring wells sampled (MW1S, MW3S, MW5S, and MW7S) and in three of the private wells sampled (Allen, Stone, and Manning) (Figure 3.1). Maximum concentrations detected were $110 \mu \mathrm{g} / \mathrm{L}$ in MW3S, $19 \mu \mathrm{g} / \mathrm{L}$ in MW1S, $18 \mu \mathrm{g} / \mathrm{L}$ in MW7S, and $7 \mu \mathrm{g} / \mathrm{L}$ in MW5S. Values detected in the private wells were $10 \mu \mathrm{g} / \mathrm{L}$ in the Stone well, $8.7 \mu \mathrm{g} / \mathrm{L}$ in the Allen well, and $6.5 \mu \mathrm{g} / \mathrm{L}$ in the Manning well. Chloroform, a degradation product of carbon tetrachloride, was detected above the quantitation limit of $1 \mu \mathrm{g} / \mathrm{L}$ in MW3S $(3.2 \mu \mathrm{g} / \mathrm{L})$ and in the Allen private well $(5.7 \mu \mathrm{g} / \mathrm{L})$. 
Carbon tetrachloride and chloroform were not detected above the quantitation limit of $1 \mu \mathrm{g} / \mathrm{L}$ in any of the other wells sampled. Methylene chloride was not detected in any of the samples.

Complete results of organic analyses on well samples are in Table C.3 in Appendix C.

\subsubsection{Major Elements}

Results of inorganic analyses of the groundwater samples were used to characterize the groundwater geochemistry and ionic compositions. Nitrate (as nitrogen) concentrations in groundwater ranged from $19.5 \mathrm{mg} / \mathrm{L}$ to $0.3 \mathrm{mg} / \mathrm{L}$ in the monitoring wells screened in the upper aquifer. No nitrate was detected (quantitation limit, $0.2 \mathrm{mg} / \mathrm{L}$ ) in well MW1D, which is screened in the deeper aquifer zone. Nitrate detected in the private wells ranged from $18.2 \mathrm{mg} / \mathrm{L}$ in the Moravec well to $0.3 \mathrm{mg} / \mathrm{L}$ in the Rilinger well (Figure 3.2). Complete inorganic analytical results are in Table C.4 in Appendix C.

\subsubsection{Tritium}

Groundwater samples were analyzed for tritium to aid in the characterization of the relative ages of groundwater and the relative contribution of rainwater recharge to the groundwater system. The decision to collect the tritium data was made during the sampling event. Tritium values ranged from 0.22 to $8.02 \mathrm{TU}$ (tritium units) in the samples analyzed. Complete analytical results are in Table C.5 of Appendix C.

\subsection{Groundwater Level Data}

The depth to groundwater measured on July 15, 2004, for the eight wells in the shallow aquifer zone (MW1S-MW8S) and the one well in the deep aquifer (MW1D) are presented in Table D.1 in Appendix D. Long-term recording transducers were installed in each monitoring well subsequently to track and record seasonal variations in groundwater levels. These data will be analyzed over time to determine the groundwater gradient and to assess the magnitude of any seasonal variations. 


\subsection{Results of Quality Control Activities}

Quality control parameters were met for sample collection and handling and for the organic, inorganic, and tritium analyses, as described in detail in the QC report in Appendix E.

Analytical results for a field blank, equipment rinsates, and trip blanks indicate that sample collection and handling procedures were followed and that carbon tetrachloride and chloroform contamination detected in the groundwater samples did not result from cross-contamination of the samples during collection or shipment. Likewise, analytical results for method blanks indicate that cross-contamination did not occur during analysis.

Low relative percent difference values between the primary samples and secondary QC samples (blind replicate samples and duplicate laboratory analyses) indicate that good precision was achieved in the analyses. Therefore, organic analytical results are acceptable for delineation of the contaminant plume, and inorganic and tritium analytical results are acceptable for characterization of the groundwater geochemistry. 


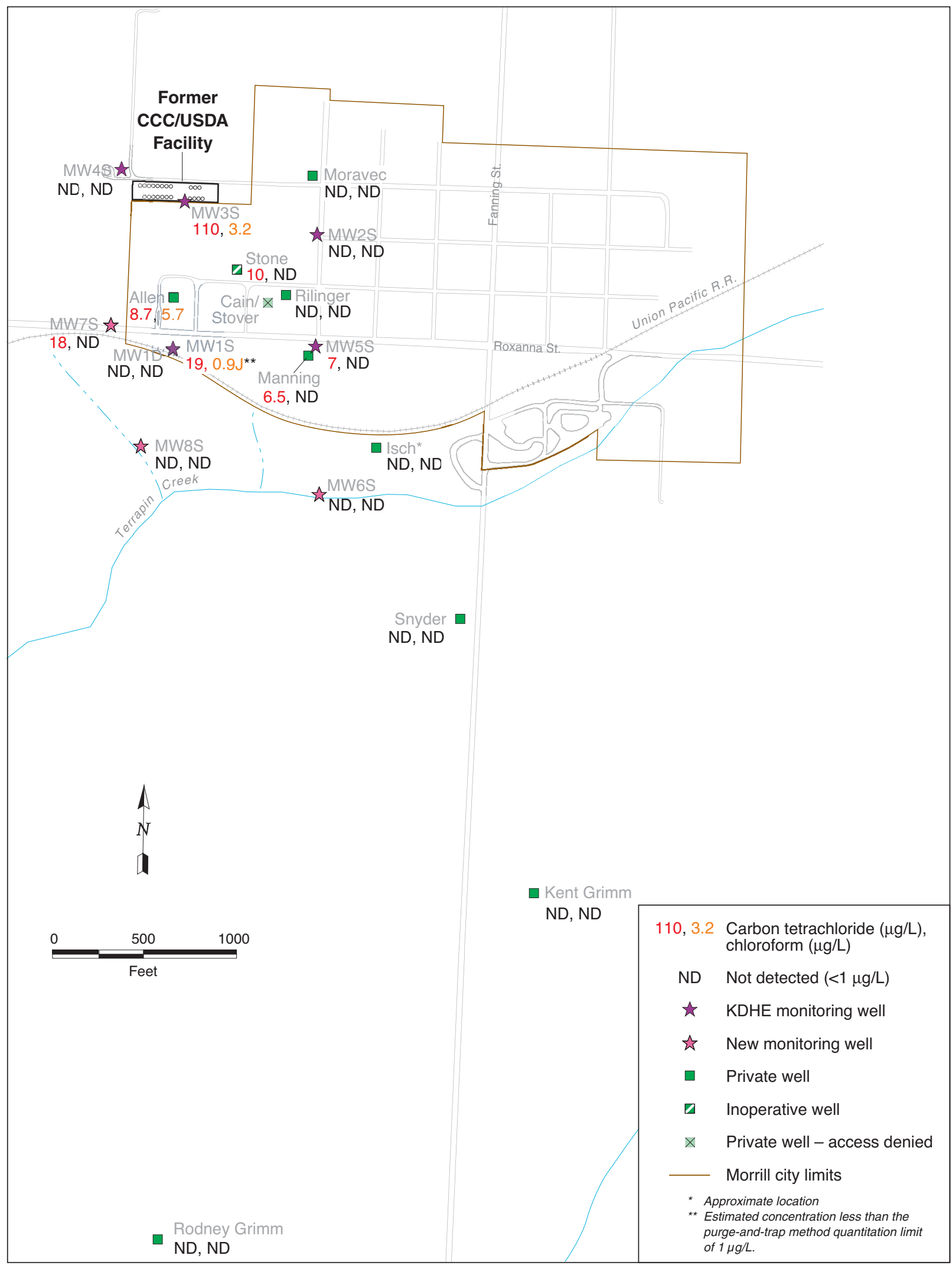

FIGURE 3.1 Carbon tetrachloride and chloroform concentrations in groundwater at Morrill, 2004. 


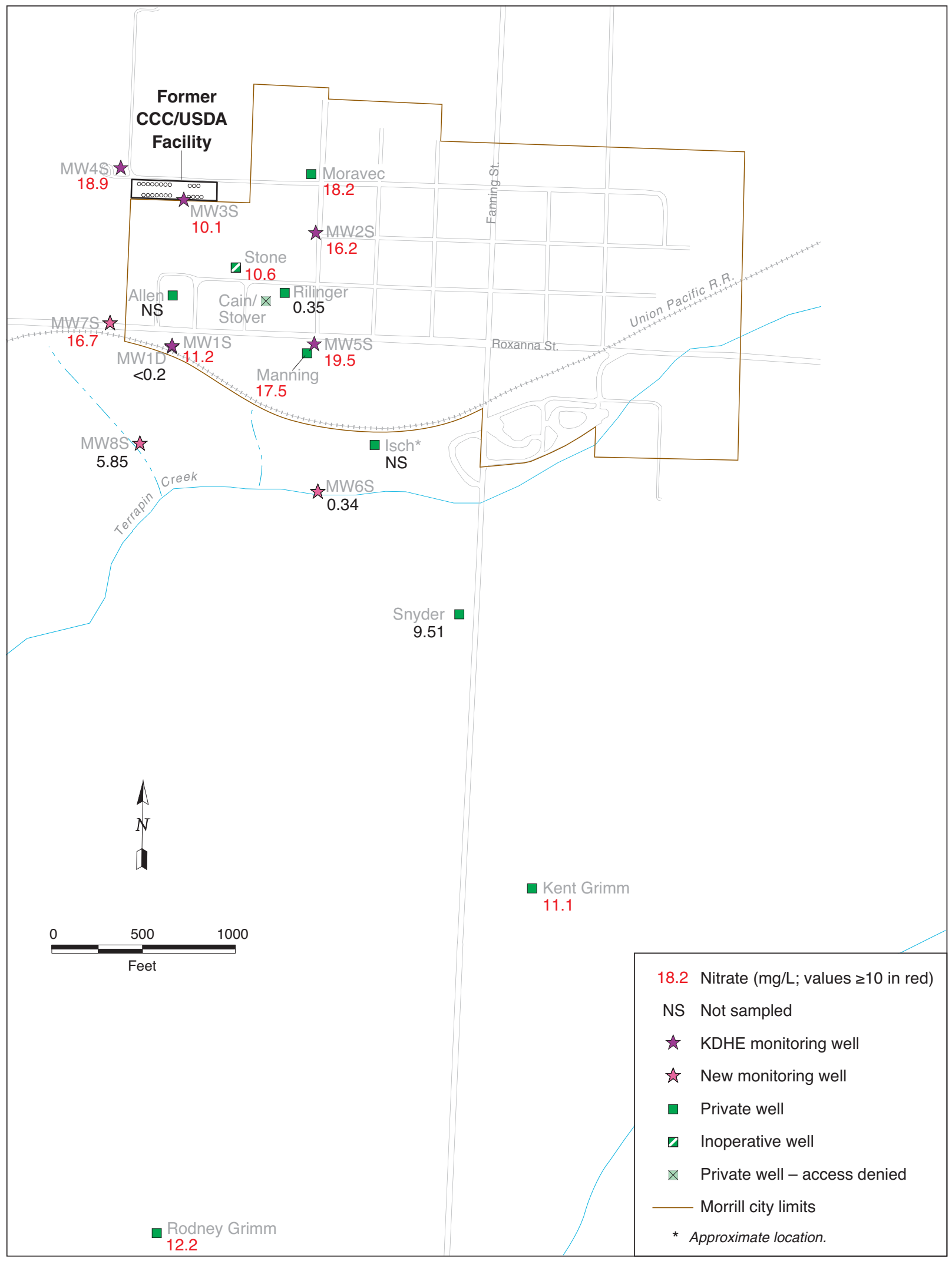

FIGURE 3.2 Nitrate concentrations in groundwater at Morrill, 2004. 


\section{Interpretation of Field and Laboratory Data}

\subsection{Groundwater Gradient}

The potentiometric surface of the upper aquifer in the investigation area over time is depicted in Figures 4.1 and 4.2. The contours in Figure 4.1 (top) are based on manual readings taken July 15, 2004 (Table D.1, Appendix D). The resulting 2004 contour pattern indicates a south-southeasterly gradient of approximately $0.009 \mathrm{ft} / \mathrm{ft}$ in the vicinity of the former CCC/USDA facility, consistent with the gradient depicted by Argonne in 2003 (Argonne 2004a; Figure 4.1 [bottom]) and by GeoCore in 1994 and 1995 (GeoCore 1994, 1996; see Figure 4.2).

\subsection{Delineation of the Groundwater Plume}

The distribution of carbon tetrachloride in groundwater at Morrill, as detected during sampling in June 2004, is shown in Figure 4.3. A carbon tetrachloride plume extended southsoutheasterly from the former CCC/USDA facility, toward Terrapin Creek. Review of the data indicates that the contaminated zone may not be adequately delineated by the existing monitoring wells. Slight western migration of the plume in the vicinity of Roxanne Street is evident with the detection of carbon tetrachloride in newly installed monitoring well MW7S.

\subsection{Site Conceptual Model}

The geologic/hydrogeologic model as presented in the Phase I-Phase II Interim Report (Argonne 2004a) was updated with data obtained during these most recent activities, integrating the current understanding of the geology and the hydrogeology to predict the potential contaminant migration pathway. The contaminant migration pathway is shown in cross section B-B" (Figures 4.4 and 4.5). The most likely contaminant pathway is inferred to be as follows: (1) vertical infiltration of carbon tetrachloride from the land surface through the vadose zone to the water table, followed by (2) subhorizontal south-southeastward lateral migration within the Grenola Limestone-Roca Shale in response to the prevailing hydraulic gradient. During periods of high groundwater levels, groundwater could possibly discharge into Terrapin Creek. 


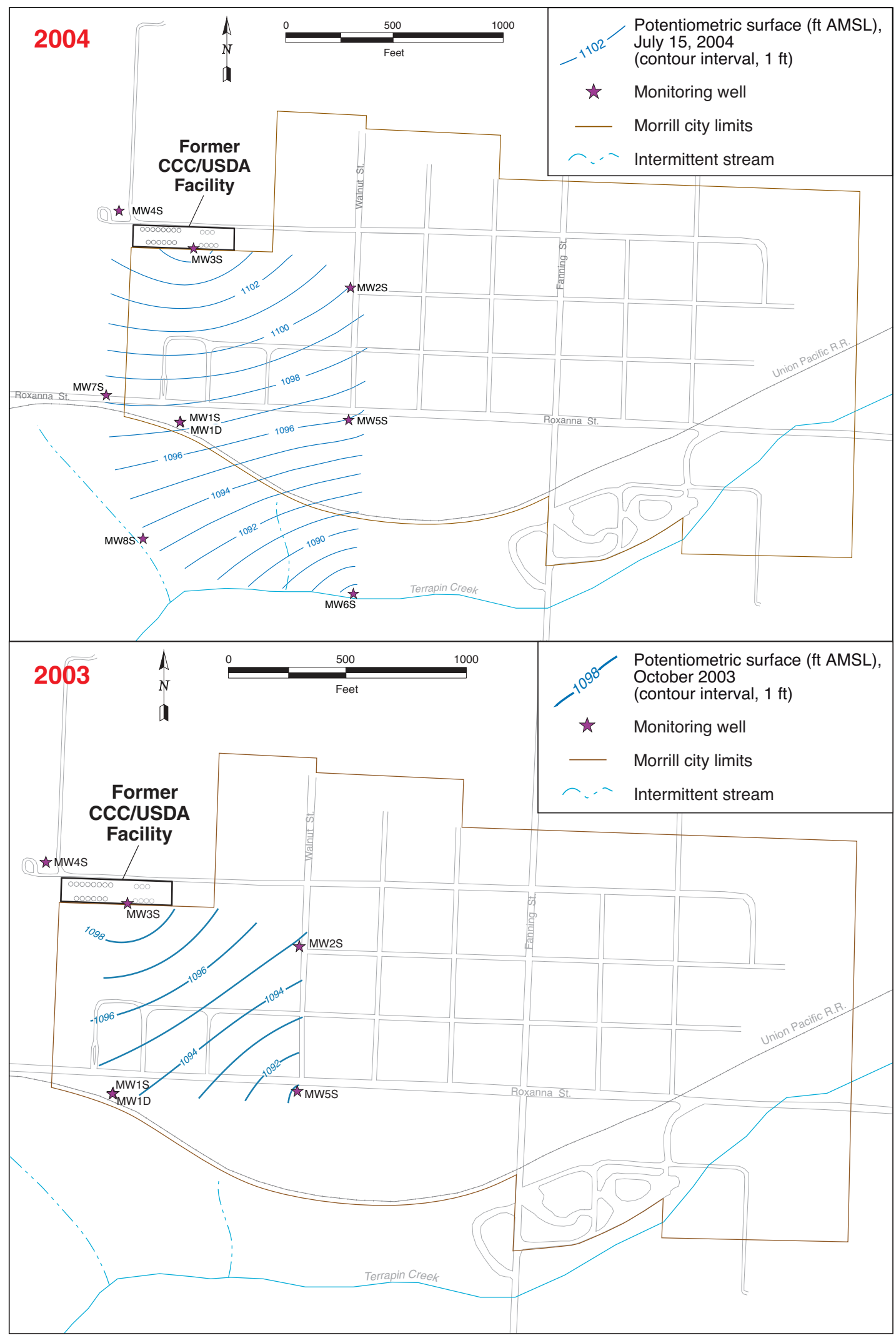

FIGURE 4.1 The potentiometric surface of the upper aquifer in the investigation area at Morrill, as measured manually on July 15, 2004 (top), and in October 2003 (bottom; from Argonne 2004a). 


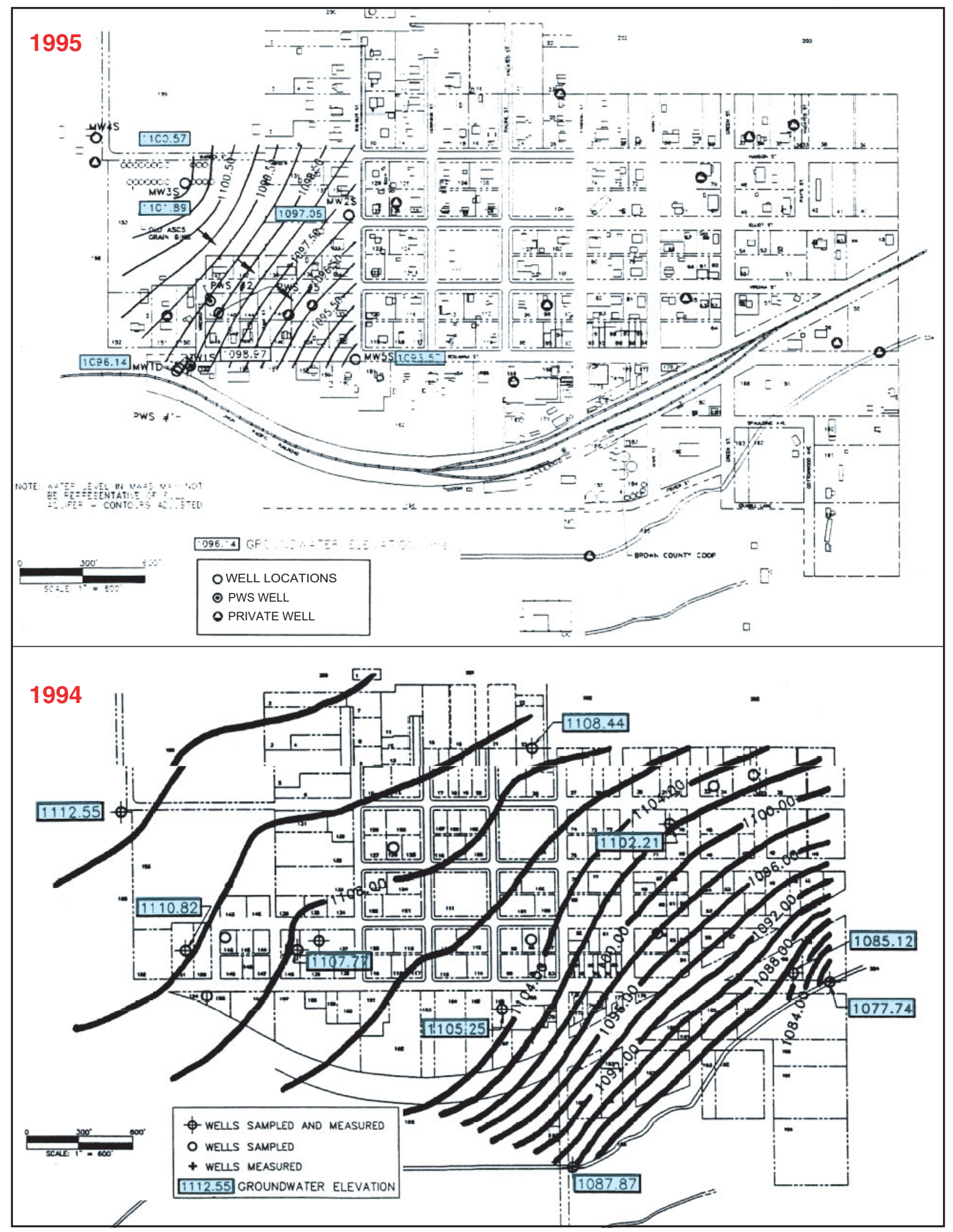

FIGURE 4.2 Local groundwater elevation contours at Morrill in 1995 and 1994. (Sources: GeoCore 1996, 1994) 


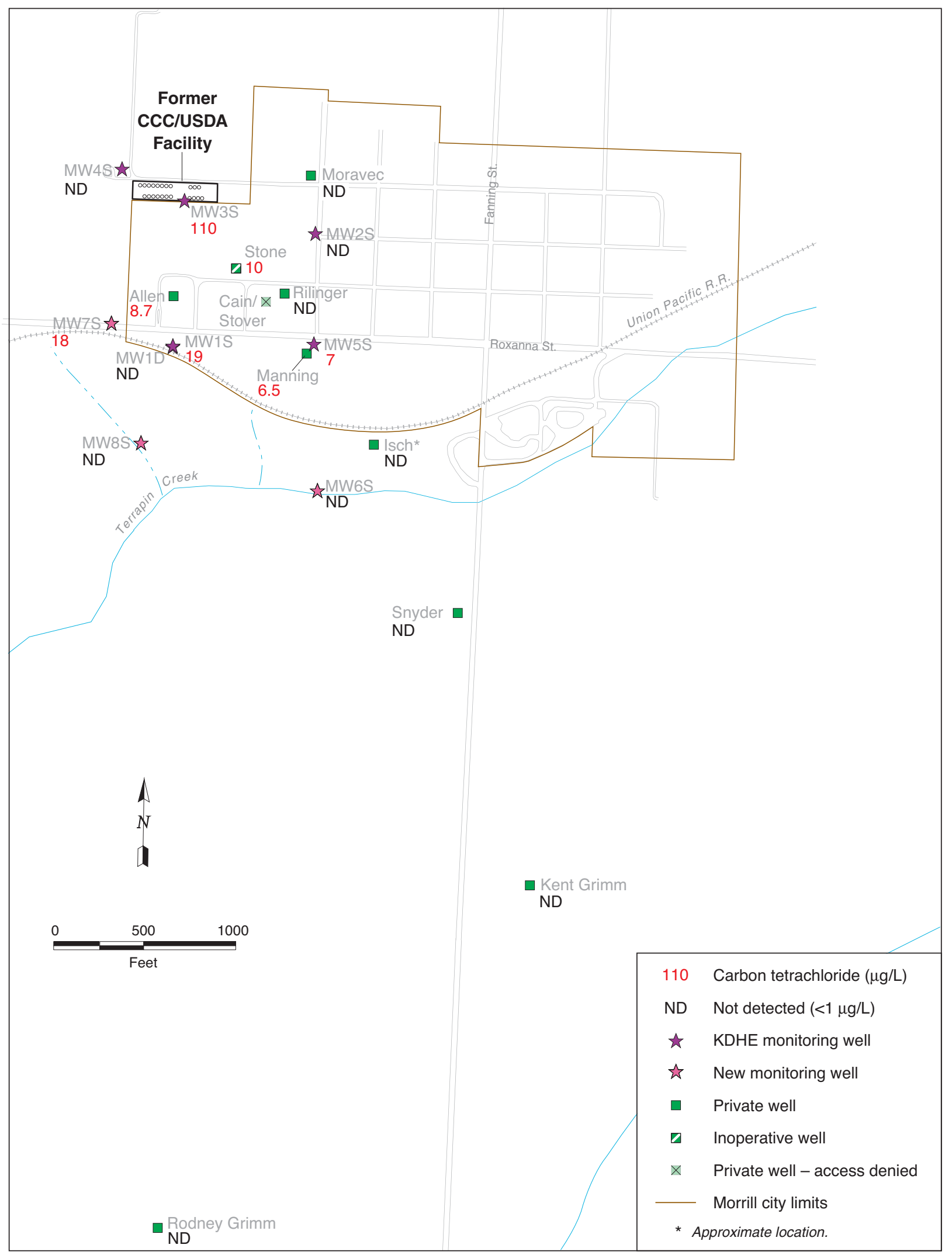

FIGURE 4.3 Distribution of carbon tetrachloride in groundwater at Morrill, on the basis of 2004 sampling results. 


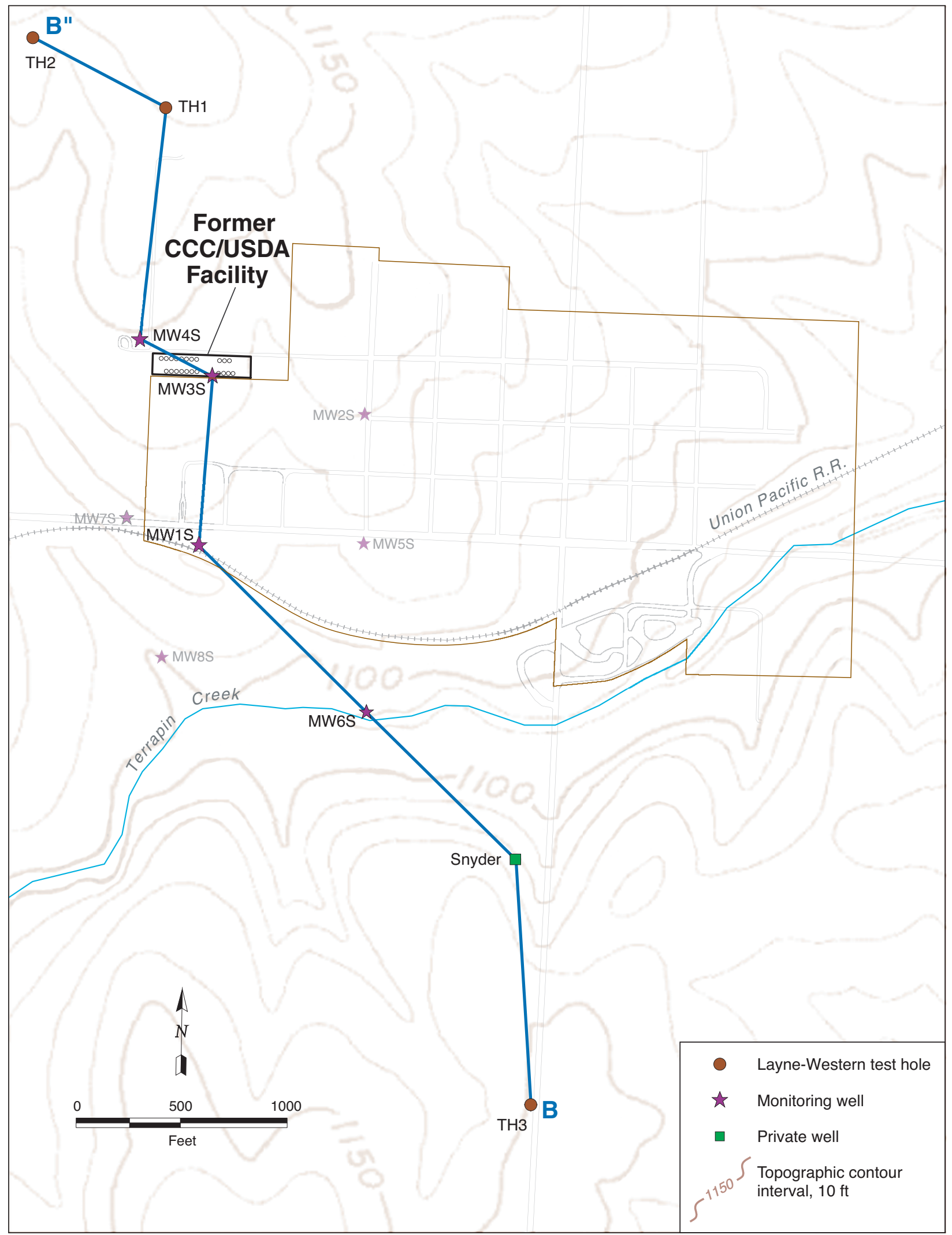

FIGURE 4.4 Location of interpretive south-north cross section B-B" in the investigation area at Morrill. 


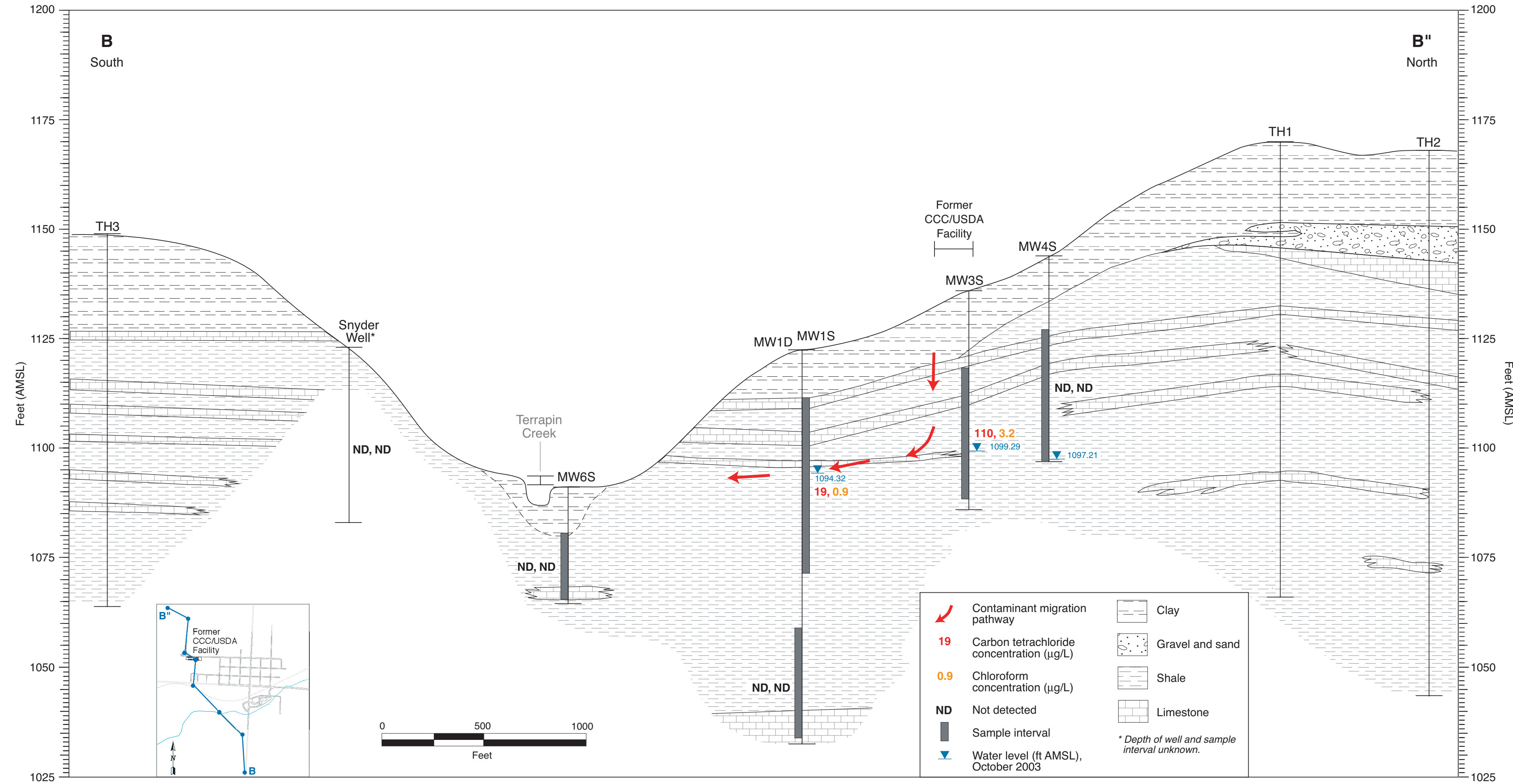

FIGURE 4.5 Inferred contaminant migration pathway at the former CCC/USDA facility at Morrill

(2004 sampling results), displayed on interpretive geologic cross section B-B" (vertically exaggerated). 


\section{Conclusions and Recommendations}

\subsection{Conclusions}

Major conclusions based on the findings of the 2004 activities and the results of the Phase I-Phase II expedited site characterization activities in 2003 (Argonne 2004a) are as follows:

- The absence of detectable concentrations of either carbon tetrachloride or chloroform above $10 \mu \mathrm{g} / \mathrm{kg}$ (the method quantitation limit) in soils to a depth of 13-15 ft BGL indicates that no unacceptable human heath risk is associated with either carbon tetrachloride or chloroform in shallow soils at the former CCC/USDA facility. Furthermore, these analytical results for soil samples collected in October 2003 indicate that no continuing soil source of carbon tetrachloride remains at the former facility.

- A groundwater plume of carbon tetrachloride in excess of the MCL of $5 \mu \mathrm{g} / \mathrm{L}$ extends downgradient from the former CCC/USDA facility.

- The contaminant plume is likely to discharge to Terrapin Creek, which serves as a groundwater drainage divide that would limit the potential southern migration of contaminated groundwater. Though presently available data do not support accurate prediction of the rate of the plume's migration, discharge to the creek within the next two years seems unlikely.

- The presence of chloroform in the groundwater suggests that biological degradation of carbon tetrachloride might be taking place in the aquifer unit.

- No domestic drinking water wells are currently impacted.

- The city of Morrill obtains its water by pipeline from the municipal water supply of Sabetha and supplies drinking water to all residences of the town of Morrill that are in the general vicinity of the existing groundwater plume. 
- The current network of groundwater monitoring wells may not delineate the extent of the plume adequately. Future expansion of the network will proceed per agreement between the CCC/USDA and the KDHE.

\subsection{Recommendations}

On the basis of the findings and conclusions of the Phase I-Phase II investigations and activities conducted at Morrill to date, the following recommendations are offered for the Morrill site:

1. A program of semiannual groundwater monitoring should be implemented to collect the data necessary to determine the rate of plume migration and confirm that in situ degradation of carbon tetrachloride is occurring. This monitoring program should continue for a minimum of two years.

The CCC/USDA and Argonne will prepare a sampling work plan containing the details of the recommended monitoring program, for submission to the KDHE for its approval.

The sampling work plan is expected to include an initial event of groundwater sampling for analyses of VOCs, plus other parameters to aid in the evaluation of bioattenuation processes.

2. Upon completion of the two-year monitoring program, remedial action objectives and potential corrective action alternatives will be developed to address the carbon tetrachloride groundwater contamination at Morrill.

3. Nitrates are present in the upper aquifer zone at Morrill, generally at levels above the MCL of $10 \mathrm{mg} / \mathrm{L}$. Concentrations found in the 2004 sampling were $0.24-19.5 \mathrm{mg} / \mathrm{L}$. The affected groundwater is not currently being used as a source of drinking water, as Morrill is supplied with drinking water via pipeline from Sabetha. Nitrates are a statewide problem associated with agricultural practices; they are not a specific responsibility of the CCC/USDA. Remediating the aquifer at Morrill to meet drinking water standards for 
carbon tetrachloride will not be meaningful if nitrate concentrations remain above the MCL. Any corrective action plan for the Morrill aquifer needs to address nitrates in addition to carbon tetrachloride.

4. The KDHE and the city of Morrill should immediately develop and enforce environmental use controls and any other means necessary to ensure that no drinking water wells are installed in the contaminant plume.

5. The KDHE should determine whether the Cain/Stover well is operational and can be sampled. Though this well is not used for drinking water, sampling it would generate useful information, if the well is operational and the KDHE can negotiate access. 


\section{References}

Argonne, 2002, Final Master Work Plan: Environmental Investigations at Former CCC/USDA Facilities in Kansas, 2002 Revision, ANL/ER/TR-02/004, prepared for the Commodity Credit Corporation, U.S. Department of Agriculture, by Argonne National Laboratory, Argonne, Illinois, December.

Argonne, 2003a, Proposed Monitoring Well Locations: Morrill, Kansas, ANL/ER/AGEM/ CHRON-640, prepared for the Commodity Credit Corporation, U.S. Department of Agriculture, by Argonne National Laboratory, Argonne, Illinois, November 25.

Argonne, 2003b, Final Work Plan: Phase I Expedited Site Characterization, Morrill, Kansas, ANL/ER/TR-03/001, prepared for the Commodity Credit Corporation, U.S. Department of Agriculture, by Argonne National Laboratory, Argonne, Illinois, September.

Argonne, 2004a, Final Phase I-Phase II Interim Report: Expedited Site Characterization, Morrill, Kansas, ANL/ER/TR-04/001, prepared for the Commodity Credit Corporation, U.S. Department of Agriculture, by Argonne National Laboratory, Argonne, Illinois, December.

Argonne, 2004b, Draft Supplemental Work Plan for Monitoring Well Installation at Morrill, Kansas, ANL/ER/AGEM/CHRON-667, prepared for the Commodity Credit Corporation, U.S. Department of Agriculture, by Argonne National Laboratory, Argonne, Illinois, February 11.

Argonne, 2004c, Addendum to the Draft Supplemental Work Plan for Monitoring Well Installation at Morrill, Kansas, ANL/ER/AGEM/CHRON-693, prepared for the Commodity Credit Corporation, U.S. Department of Agriculture, by Argonne National Laboratory, Argonne, Illinois, April 2.

EPA, 1989, USEPA Contract Laboratory Statement of Work for Organic Analysis: Multi-Media, Multi-Concentration, U.S. Environmental Protection Agency SOW No. 2/88, including Revisions $9 / 88$ and 4/89. 
EPA, 1994, USEPA Contract Laboratory Program (CLP) National Functional Guidelines for Organic Data Review, EPA540/R-94/012, Office of Emergency and Remedial Response, U.S. Environmental Protection Agency, Washington, D.C., February.

GeoCore, 1994, Preliminary Report: Phase I Sampling: Brown County Groundwater Investigation, prepared by GeoCore Services, Inc., Salina, Kansas, for the Bureau of Environmental Remediation, Kansas Department of Health and Environment, July 19.

GeoCore, 1996, Environmental Site Investigation Report: Phase II Drilling \& Sampling: Morrill Public Water Supply Well \#5, Morrill, Kansas, prepared by GeoCore Services, Inc., Salina, Kansas, for the Bureau of Environmental Remediation, Kansas Department of Health and Environment (draft issued August 31, 1995; revised February 29, 1996).

Gotto, L., 2004, memo from Gotto (Remediation Section, Bureau of Environmental Remediation, Kansas Department of Health and Environment, Topeka, Kansas) to C. Roe (Commodity Credit Corporation, U.S. Department of Agriculture, Washington, D.C.) on Addendum to the Draft Supplemental Work Plan for Monitoring Well Installation at Morrill, Kansas, April 8.

Hansen, J., 2001, unpublished information about March 20 visit to Morrill, Kansas, and Brown County courthouse, Argonne National Laboratory, Argonne, Illinois.

KDHE, 1989, Preliminary Assessment of the Morrill Public Water Supply Well \#5, Morrill, Kansas (Site Identification Number: KS D981710288), completed by R. Bean and J. Alldritt, Bureau of Environmental Remediation, Kansas Department of Health and Environment, June 6.

Surgnier, D., 2004 , telephone conversation between Surgnier (Delta Environmental Consultants, Inc.) and L. Gotto (Remediation Section, Bureau of Environmental Remediation, Kansas Department of Health and Environment, Topeka, Kansas), March 8.

USDA, 1999, aerial photograph of Morrill Kansas, NAPP-11460-31A, U.S. Department of Agriculture, Washington, D.C., March 30. 
Monitoring Well Installation and Sampling, 2004, Morrill, Kansas

\section{Appendix A:}

\section{Well Construction Diagrams}




\section{Monitor Well MW6S: Morrill, KS}

SW 1/4 of NE 1/4 of NE 1/4 of Section 35, Twp. 1 South, Rge. 15 East Brown County, State of Kansas

Date: $05 / 05 / 04$

\section{WELL HEAD PROTECTION}

12" Morrison Brothers, Co. Model 418XA flush mount cover. Top of casing fitted with a (J-Plug) Morrison Brothers, Co. Model 678XA and a padlock.

\section{CONCRETE PAD}

8 " thick and extends 8 " larger than the flush mount (28" minimum). Sloped to prevent pooling of water and vegetation around well and to allow for placement of a surveyor pin.

\section{IMPERVIOUS GROUT}

The well is grouted with bentonite grout as required, mixed with clean fresh water.

\section{WELL CASING}

Well casing is terminated as high as possible inside the flush mount and is capped with a (J-Plug) Morrison Brothers, Co. Model 678XA locking plug and padlock.

4" PVC Sch 40, threaded casing and PVC, Mill Slot (0.020") well screen.

\section{HOLE SIZE}

The hole is $8^{\prime \prime}$ in diameter from the surface to (27') T.D. and grouted from the top of the sand pack to the base of the flush mount.

\section{GRAVEL / SAND PACK}

Gravel pack is designed to stabilize the aquifer material and permit the fine fraction to move into the well during development. Gravel/sand pack extends to at least 2' above screen.

\section{CONTRACTOR LICENSING}

The well was constructed under the direction of a licensed water well contractor as specified under the Kansas Department of Health and Environment regulation.

\section{REGISTRATION}

The well was registered with the Kansas Department of Health and Environment on form WWC-5.

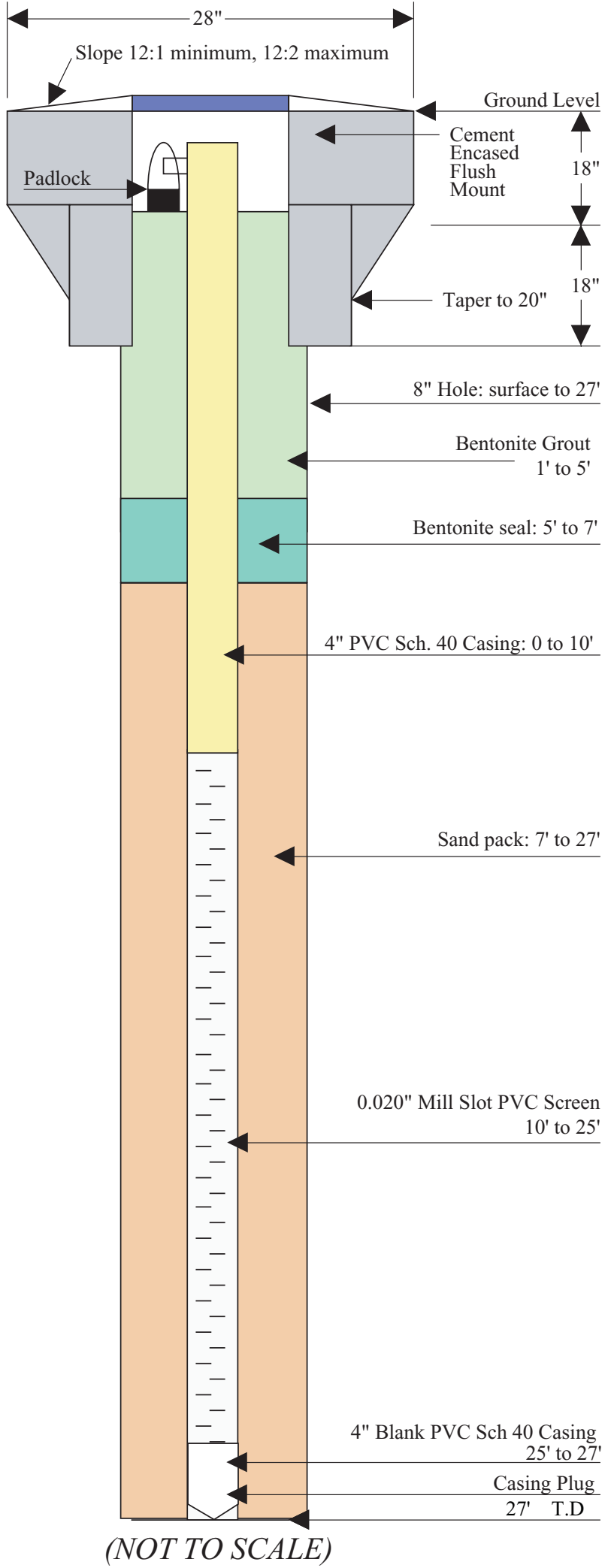




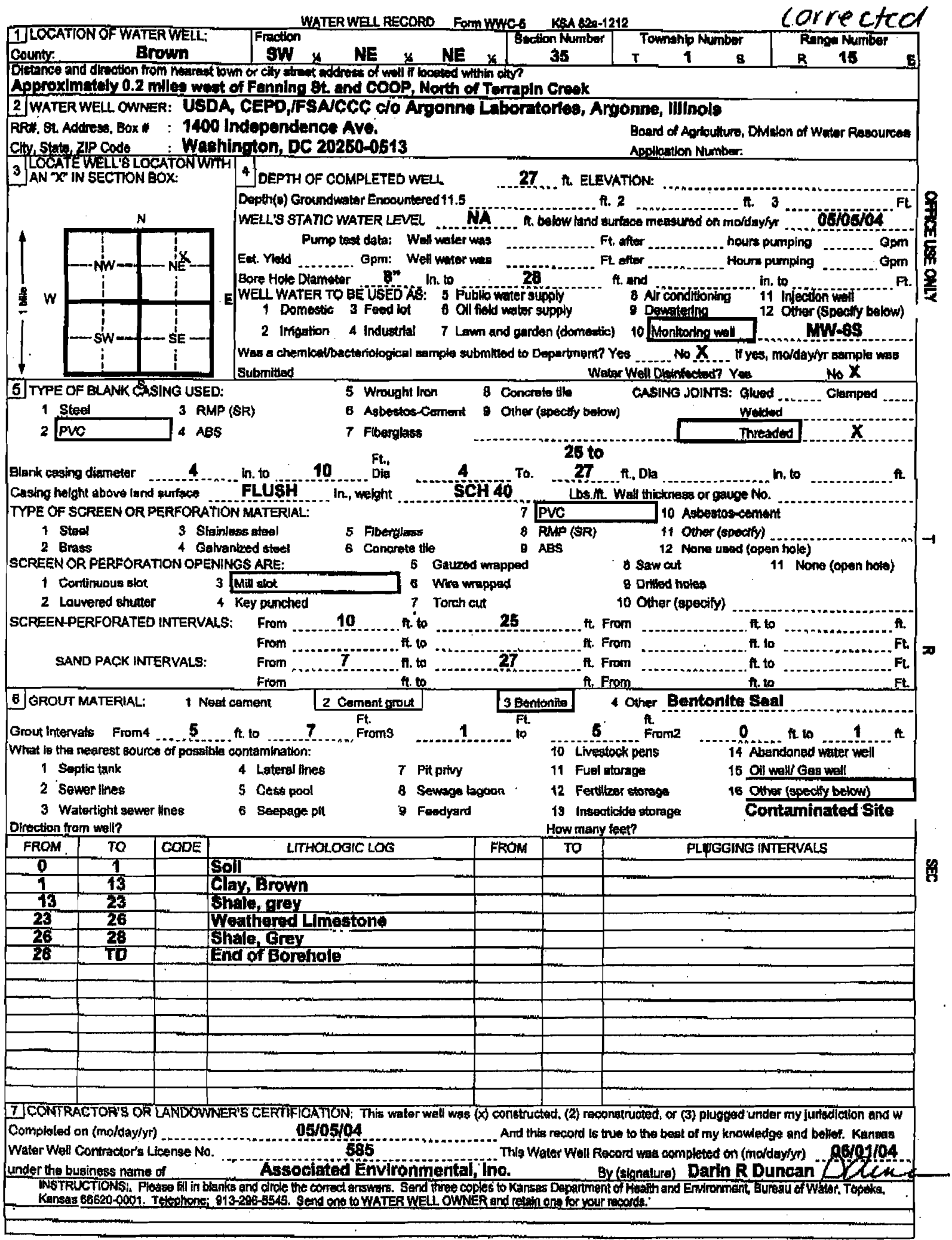




\section{Monitor Well MW7S: Morrill, KS}

SW 1/4 of SW 1/4 of SE 1/4 of Section 26, Twp. 1 South, Rge. 15 East Brown County, State of Kansas

Date: 05/05/04

\section{WELL HEAD PROTECTION}

12" Morrison Brothers, Co. Model 418XA flush mount cover. Top of casing fitted with a (J-Plug) Morrison Brothers, Co. Model 678XA and a padlock.

\section{CONCRETE PAD}

8 " thick and extends 8 " larger than the flush mount (28" minimum). Sloped to prevent pooling of water and vegetation around well and to allow for placement of a surveyor pin.

\section{IMPERVIOUS GROUT}

The well is grouted with bentonite grout as required, mixed with clean fresh water.

\section{WELL CASING}

Well casing is terminated as high as possible inside the flush mount and is capped with a (J-Plug) Morrison Brothers, Co. Model 678XA locking plug and padlock.

4" PVC Sch 40, threaded casing and PVC, Mill Slot (0.020") well screen.

\section{HOLE SIZE}

The hole is $8^{\prime \prime}$ in diameter from the surface to (47') T.D. and grouted from the top of the sand pack to the base of the flush mount.

\section{GRAVEL / SAND PACK}

Gravel pack is designed to stabilize the aquifer material and permit the fine fraction to move into the well during development. Gravel/sand pack extends to at least 2' above screen.

\section{CONTRACTOR LICENSING}

The well was constructed under the direction of a licensed water well contractor as specified under the Kansas Department of Health and Environment regulation.

\section{REGISTRATION}

The well was registered with the Kansas Department of Health and Environment on form WWC-5.

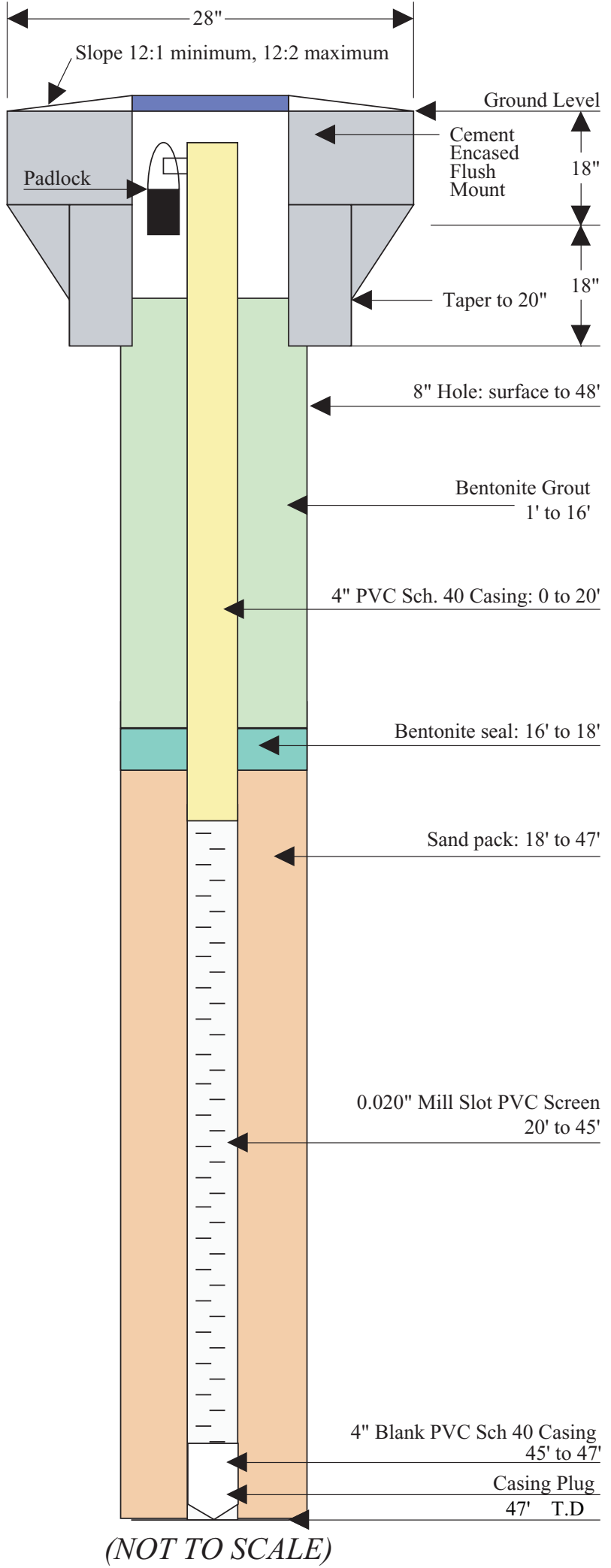




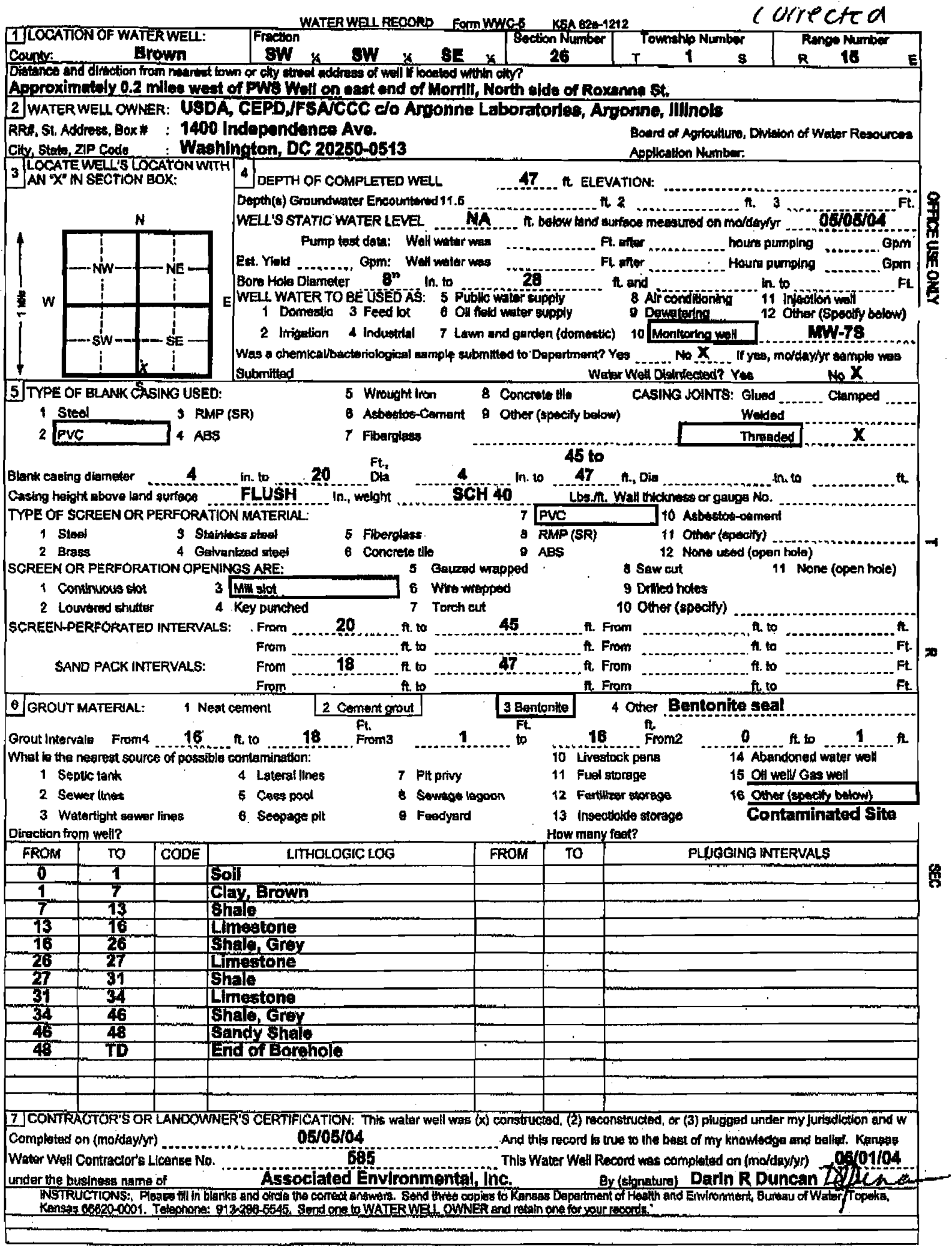




\section{Monitor Well MW8S: Morrill, KS}

SE 1/4 of NW 1/4 of NE 1/4 of Section 35, Twp. 1 South, Rge. 15 East Brown County, State of Kansas

Date: $05 / 05 / 04$

\section{WELL HEAD PROTECTION}

12" Morrison Brothers, Co. Model 418XA flush mount cover. Top of casing fitted with a (J-Plug) Morrison Brothers, Co. Model 678XA and a padlock.

\section{CONCRETE PAD}

8 " thick and extends 8 " larger than the flush mount (28" minimum). Sloped to prevent pooling of water and vegetation around well and to allow for placement of a surveyor pin.

\section{IMPERVIOUS GROUT}

The well is grouted with bentonite grout as required, mixed with clean fresh water.

\section{WELL CASING}

Well casing is terminated as high as possible inside the flush mount and is capped with a (J-Plug) Morrison Brothers, Co. Model 678XA locking plug and padlock.

4" PVC Sch 40, threaded casing and PVC, Mill Slot (0.020") well screen.

\section{HOLE SIZE}

The hole is $8^{\prime \prime}$ in diameter from the surface to (27') T.D. and grouted from the top of the sand pack to the base of the flush mount.

\section{GRAVEL / SAND PACK}

Gravel pack is designed to stabilize the aquifer material and permit the fine fraction to move into the well during development. Gravel/sand pack extends to at least 2' above screen.

\section{CONTRACTOR LICENSING}

The well was constructed under the direction of a licensed water well contractor as specified under the Kansas Department of Health and Environment regulation.

\section{REGISTRATION}

The well was registered with the Kansas Department of Health and Environment on form WWC-5.

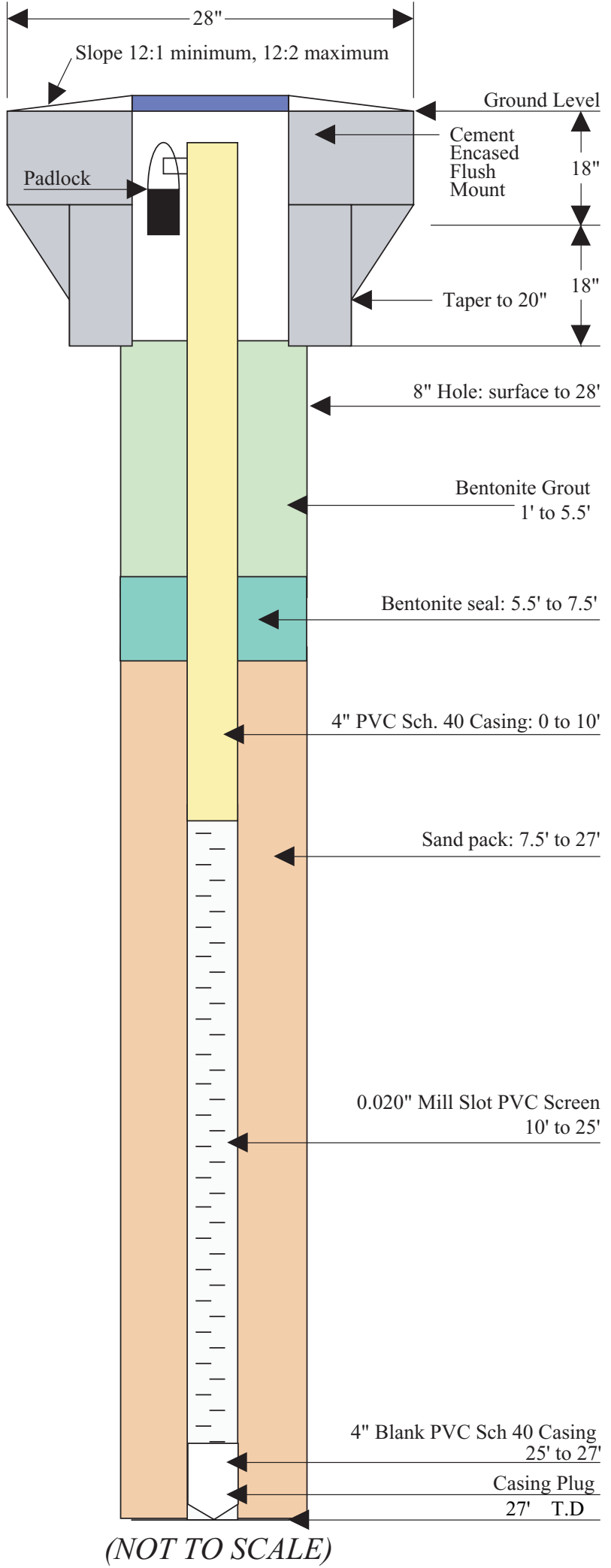




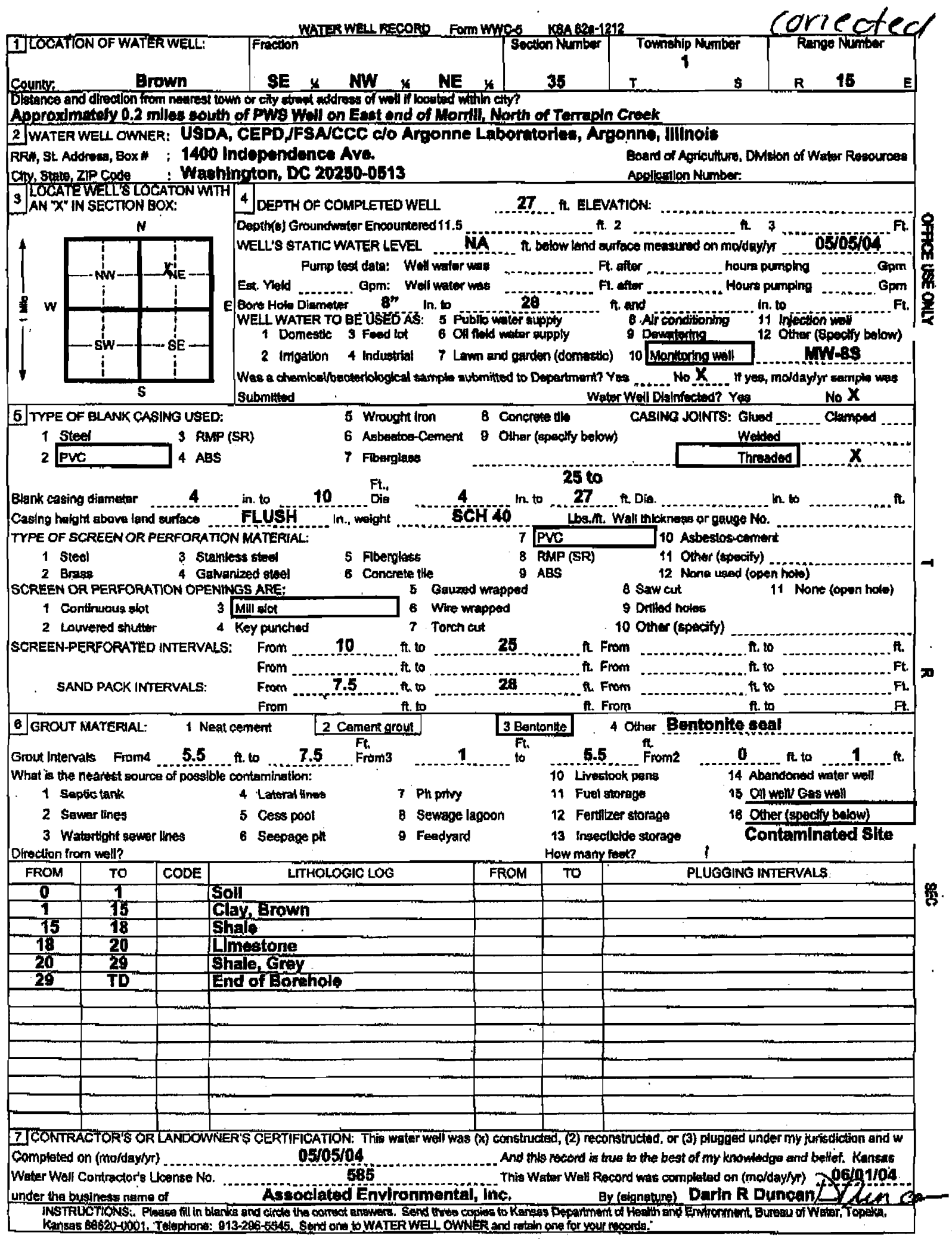




\section{Appendix B:}

Coordinates Survey Data 
TABLE B.1 Survey data for monitoring wells at Morrill, Kansas.

\begin{tabular}{|c|c|c|c|c|}
\hline \multirow[b]{3}{*}{ Location } & \multirow{2}{*}{\multicolumn{2}{|c|}{ Horizontal Location ${ }^{\mathrm{a}}(\mathrm{ft})$}} & \multicolumn{2}{|c|}{ Elevation $^{\mathrm{b}}$ (ft AMSL) } \\
\hline & & & \multirow{2}{*}{$\begin{array}{l}\text { Representative } \\
\text { Ground Surface }\end{array}$} & \multirow[b]{2}{*}{ Reference } \\
\hline & Northing & Easting & & \\
\hline MW1S & 589130.20 & 1957316.76 & 1122.3 & 1124.68 \\
\hline MW1D & 589129.06 & 1957314.45 & 1122.2 & 1124.63 \\
\hline MW2S & 589789.61 & 1958063.43 & 1137.3 & 1137.07 \\
\hline MW3S & 589929.06 & 1957333.78 & 1136.0 & 1135.76 \\
\hline MW4S & 590083.24 & 1956982.15 & 1143.8 & 1143.61 \\
\hline MW5S & 589182.24 & 1958089.03 & 1122.4 & 1122.21 \\
\hline MW6S & 588385.33 & 1958149.44 & 1091.4 & 1090.97 \\
\hline MW7S & 589238.96 & 1956967.99 & 1120.4 & 1119.86 \\
\hline MW8S & 588590.43 & 1957169.82 & 1099.0 & 1098.53 \\
\hline
\end{tabular}

a Horizontal coordinates are target location centers. Northings and Eastings are Kansas State Plane Coordinates. Horizontal datum is North American Datum (NAD) 83.

b Vertical datum is National Geodetic Vertical Datum (NGVD) 88.

c Top of casing.

Source: Schwab-Eaton, Manhattan, Kansas. 


\section{Appendix C:}

\section{Groundwater Sample Data}


TABLE C.1 Groundwater samples collected during the 2004 sampling events at Morrill, Kansas.

\begin{tabular}{|c|c|c|c|c|}
\hline Location & Sample & $\begin{array}{l}\text { Depth } \\
\text { (ft BGL) }\end{array}$ & $\begin{array}{c}\text { Sample } \\
\text { Date }\end{array}$ & Description \\
\hline
\end{tabular}

Private wells

$\begin{array}{llc}\begin{array}{l}\text { Isch } \\ \text { K. Grimm }\end{array} & \begin{array}{l}\text { MRJR-W-16502 } \\ \text { Manning }\end{array} & \begin{array}{c}\text { Unk }^{\mathrm{a}} \\ \text { Unk-100 }\end{array} \\ \text { R. Grimm } & \text { MRPRIVCAI-W-16472 } & \text { Unk } \\ \text { Rilinger } & \text { MRPRIVRGRI-W-16477 } & \text { Unk } \\ \text { Snyder } & \text { MRPRIVSNY-W-164746 } & \text { Unk-47 } \\ & & \\ \text { Stone } & \text { MRPRIVSTON-W-16475 } & \text { Unk-43 } \\ & & \\ \text { Moravec } & \text { MRPRIVMOR-W- } & \text { Unk } \\ \text { Allen } & \text { MR456/16448/16446 } & \\ & \text { MRALLEN-W-16505 } & \text { Unk }\end{array}$

2/19/04 Sample from J.R. Isch drinking water well.

6/4/04 Kent Grimm residence. Well depth reported at $100 \mathrm{ft}$. Sampled at spigot about $25 \mathrm{ft}$ north of house.

6/4/04 Hand pump well at property owned by Dave Manning and occupied by Marie Cain. Water use reported by resident as drinking water for dogs. Sampled after purging 10 gal.

6/4/04 Rodney Grimm residence. Two wells mixed. Water used for residence, livestock, and in shop.

6/4/04 Larry Rilinger lawn and garden well by decorative fence near garden. Residence on Walnut Street. Depth unknown; 6 in. steel casing. Sampled after running for 5 minutes.

6/4/04 Lowell Snyder is owner of residence, also known as Avis Miller residence. Renter not specified in log. Depth to water from top of casing $(T O C)=30.85 \mathrm{ft}$. Depth of well $=47 \mathrm{ft}$. Sample collected after purging $126 \mathrm{gal}$. Well is 8 in. steel casing.

6/4/04 James Stone residence on Virginia Street. Depth to water from TOC $=23.35 \mathrm{ft}$. Depth of well uncertain. Purged dry quickly at $2-3 \mathrm{gpm}$, reduced rate to $0.38 \mathrm{gpm}$.

6/16/04 Sample from Moravec private well. Sample 16456 used for organic analysis. Sample 16448 used for inorganic analysis. Sample 16446 used for tritium analysis.

8/27/04 Unused, hand-dug well at Allen residence, approximately 36-in. diameter, stone-lined. Handpump not functional. Measured depth to water from concrete slab at ground level $=33.7 \mathrm{ft}$. Depth of well $=39.5 \mathrm{ft}$, but has approximately $3 \mathrm{ft}$ of sludge at bottom. Sample collected without purge.

\section{Monitoring wells}

$\begin{array}{lll}\text { MW6S } & \text { MRMW-S6-16440/16441 } & 10-25 \\ \text { MW7S } & \text { MRMW-S7-16442/16444 } & 20-45 \\ \text { MW8S } & \text { MRMW-S8-16438/16439 } & 10-25 \\ & & \\ \text { MW1S } & \text { MRMW1S-W-16461 } & 11-51 \\ \text { MW1D } & \text { MRMW1D-W-16458 } & 63-88 \\ \text { MW2S } & \text { MRMW2S-W-16459 } & 13-53\end{array}$

5/10/04 Sample from MW6S for inorganic analysis just after installation and development. Sample 16440 used for anions analysis. Sample 16441 used for cations analysis.

5/10/04 Sample from MW7S for inorganic analysis just after installation and development. Sample 16442 used for anions analysis. Sample 16444 used for cations analysis.

5/10/04 Sample from MW8S for inorganic analysis just after installation and development. Sample 16438 used for anions analysis. Sample 16439 used for cations analysis.

6/2/04 Depth to water from TOC $=26.97 \mathrm{ft}$. Depth of well $=53.94 \mathrm{ft}$. Sample collected after purging 53 gal.

6/2/04 Depth to water from TOC $=26.82 \mathrm{ft}$. Depth of well $=88.6 \mathrm{ft}$. Sample collected after purging 140 gal.

6/2/04 Depth to water from TOC $=37.44 \mathrm{ft}$. Depth of well $=53.3 \mathrm{ft}$. Sample collected after purging 31 gal. Purged dry twice during purge. 
TABLE C.1 (Cont.)

\begin{tabular}{|c|c|c|c|c|}
\hline Location & Sample & $\begin{array}{l}\text { Depth } \\
\text { (ft BGL) }\end{array}$ & $\begin{array}{l}\text { Sample } \\
\text { Date }\end{array}$ & Description \\
\hline \multicolumn{5}{|c|}{ Monitoring wells (Cont.) } \\
\hline MW3S & MRMW3S-W-16462 & $18-48$ & $6 / 2 / 04$ & $\begin{array}{l}\text { Depth to water from TOC }=30.67 \mathrm{ft} \text {. Depth of well }=47.5 \mathrm{ft} \text {. Sample collected after purging } \\
34 \text { gal. }\end{array}$ \\
\hline MW4S & MRMW4S-W-16470 & $17-47$ & $6 / 4 / 04$ & $\begin{array}{l}\text { Depth to water from TOC }=43.21 \mathrm{ft} \text { on June } 3 . \text { Depth to water }=44.42 \text { on June } 4 . \text { Depth of } \\
\text { well }=47.80 \mathrm{ft} \text {. Sample collected after purging } 10 \text { gal. Purged dry repeatedly. Sampled } \\
\text { after overnight recharge. }\end{array}$ \\
\hline MW5S & MRMW5S-W-16460 & $15-55$ & $6 / 2 / 04$ & $\begin{array}{l}\text { Depth to water from TOC }=26.33 \mathrm{ft} \text {. Depth of well }=55.65 \mathrm{ft} \text {. Sample collected after purging } \\
>57 \text { gal. }\end{array}$ \\
\hline MW6S & MRMW6S-W-16465 & $10-25$ & $6 / 3 / 04$ & $\begin{array}{l}\text { Depth to water from TOC }=3.34 \mathrm{ft} \text {. Depth of well }=26.90 \mathrm{ft} \text {. Sample collected after purging } \\
45 \text { gal. }\end{array}$ \\
\hline MW7S & MRMW7S-W-16466 & $20-45$ & $6 / 3 / 04$ & $\begin{array}{l}\text { Depth to water from TOC recorded incorrectly. Depth of well }=46.98 \mathrm{ft} \text {. Sample collected } \\
\text { after purging } 40 \text { gal. }\end{array}$ \\
\hline MW8S & MRMW8S-W-16464 & $10-25$ & $6 / 3 / 04$ & $\begin{array}{l}\text { Depth to water from TOC }=3.70 \mathrm{ft} \text {. Depth of well }=26.75 \mathrm{ft} \text {. Sample collected after purging } \\
45 \text { gal. }\end{array}$ \\
\hline
\end{tabular}

a Unk, unknown depth. 
Monitoring Well Installation and Sampling, Morrill, Kansas

Version 00, 11/18/04

C-4

TABLE C.2 Field measurements during the 2004 sampling events at Morrill, Kansas.

\begin{tabular}{|c|c|c|c|c|c|c|}
\hline Location & Sample & $\begin{array}{l}\text { Depth } \\
\text { (ft BGL) }\end{array}$ & $\begin{array}{l}\text { Sample } \\
\text { Date }\end{array}$ & $\begin{array}{c}\text { Temperature } \\
\left({ }^{\circ} \mathrm{C}\right)\end{array}$ & $\mathrm{pH}$ & $\begin{array}{l}\text { Conductivity } \\
\qquad(\mu \mathrm{S} / \mathrm{cm})\end{array}$ \\
\hline K. Grimm & MRPRIVKGR-W-16474 & Unk ${ }^{a}-100$ & $6 / 4 / 04$ & 20.1 & 7.28 & 825 \\
\hline Manning & MRPRIVCAI-W-16472 & Unk & $6 / 4 / 04$ & 11 & 7.24 & 899 \\
\hline R. Grimm & MRPRIVRGRI-W-16477 & Unk & $6 / 4 / 04$ & $N R^{b}$ & NR & NR \\
\hline Rilinger & MRPRIVRIL-W-16471 & Unk & $6 / 4 / 04$ & 15.9 & 6.99 & 2,450 \\
\hline Snyder & MRPRIVSNY-W-16476 & Unk-47 & $6 / 4 / 04$ & 15.6 & 7.06 & 1,770 \\
\hline Stone & MRPRIVSTON-W-16475 & Unk-43 & $6 / 4 / 04$ & 17.1 & 7.35 & 682 \\
\hline Moravec & MRPRIVMOR-W-16456 & Unk & $6 / 16 / 04$ & NR & NR & NR \\
\hline Allen & MRALLEN-W-16505 & Unk & $8 / 27 / 04$ & 21.6 & 6.85 & 712 \\
\hline MW1S & MRMW1S-W-16461 & $11-51$ & $6 / 2 / 04$ & 14.4 & 7.16 & 970 \\
\hline MW1D & MRMW1D-W-16458 & $63-88$ & $6 / 2 / 04$ & 13.9 & 6.87 & 2,460 \\
\hline MW2S & MRMW2S-W-16459 & $13-53$ & $6 / 2 / 04$ & 16.9 & 7.07 & 861 \\
\hline MW3S & MRMW3S-W-16462 & $18-48$ & $6 / 2 / 04$ & 14.2 & 7.23 & 664 \\
\hline MW4S & MRMW4S-W-16470 & $17-47$ & $6 / 4 / 04$ & 15.4 & 6.93 & 769 \\
\hline MW5S & MRMW5S-W-16460 & $15-55$ & $6 / 2 / 04$ & 14.3 & 7.21 & 817 \\
\hline MW6S & MRMW6S-W-16465 & $10-25$ & $6 / 3 / 04$ & 15.1 & 6.89 & 2,410 \\
\hline MW7S & MRMW7S-W-16466 & $20-45$ & $6 / 3 / 04$ & 13.8 & 7.19 & 763 \\
\hline MW8S & MRMW8S-W-16464 & $10-25$ & $6 / 3 / 04$ & 12.8 & 7.12 & 941 \\
\hline
\end{tabular}

a Unk, unknown depth.

b NR, measurement not recorded. 
TABLE C.3 Results of analyses for VOCs on groundwater samples collected during the 2004 sampling events at Morrill, Kansas.

\begin{tabular}{|c|c|c|c|c|c|c|}
\hline \multirow[b]{2}{*}{ Location } & \multirow[b]{2}{*}{ Sample } & \multirow[b]{2}{*}{$\begin{array}{l}\text { Depth } \\
\text { (ft BGL) }\end{array}$} & \multirow[b]{2}{*}{$\begin{array}{l}\text { Sample } \\
\text { Date }\end{array}$} & \multicolumn{3}{|c|}{ Concentration $(\mu \mathrm{g} / \mathrm{L})$} \\
\hline & & & & $\begin{array}{c}\text { Carbon } \\
\text { Tetrachloride }\end{array}$ & Chloroform & $\begin{array}{c}\text { Methylene } \\
\text { Chloride }\end{array}$ \\
\hline Isch & MRJR-W-16502 & Unk $^{a}$ & $2 / 19 / 04$ & $N D^{b}$ & ND & ND \\
\hline K. Grimm & MRPRIVKGR-W-16474 & Unk-100 & $6 / 4 / 04$ & ND & ND & ND \\
\hline Manning & MRPRIVCAI-W-16472 & Unk & $6 / 4 / 04$ & 6.5 & ND & ND \\
\hline R. Grimm & MRPRIVRGRI-W-16477 & Unk & $6 / 4 / 04$ & ND & ND & ND \\
\hline Rilinger & MRPRIVRIL-W-16471 & Unk & $6 / 4 / 04$ & ND & ND & ND \\
\hline Snyder & MRPRIVSNY-W-16476 & Unk-47 & $6 / 4 / 04$ & ND & ND & ND \\
\hline Stone & MRPRIVSTON-W-16475 & Unk-43 & $6 / 4 / 04$ & 10 & ND & ND \\
\hline Moravec & MRPRIVMOR-W-16456 & Unk & $6 / 16 / 04$ & ND & ND & ND \\
\hline Allen & MRALLEN-W-16505 & Unk & $8 / 27 / 04$ & 8.7 & 5.7 & ND \\
\hline MW1S & MRMW1S-W-16461 & $11-51$ & $6 / 2 / 04$ & 19 & $0.9 \mathrm{Jc}$ & ND \\
\hline MW1D & MRMW1D-W-16458 & $63-88$ & $6 / 2 / 04$ & ND & ND & ND \\
\hline MW2S & MRMW2S-W-16459 & $13-53$ & $6 / 2 / 04$ & ND & ND & ND \\
\hline MW3S & MRMW3S-W-16462 & $18-48$ & $6 / 2 / 04$ & 110 & 3.2 & ND \\
\hline MW4S & MRMW4S-W-16470 & $17-47$ & $6 / 4 / 04$ & ND & ND & ND \\
\hline MW5S & MRMW5S-W-16460 & $15-55$ & $6 / 2 / 04$ & 7 & ND & ND \\
\hline MW6S & MRMW6S-W-16465 & $10-25$ & $6 / 3 / 04$ & ND & ND & ND \\
\hline MW7S & MRMW7S-W-16466 & $20-45$ & $6 / 3 / 04$ & 18 & ND & ND \\
\hline MW8S & MRMW8S-W-16464 & $10-25$ & $6 / 3 / 04$ & ND & ND & ND \\
\hline
\end{tabular}

a Unk, unknown depth.

b ND, contaminant not detected.

c J, estimated concentration below the purge-and-trap method quantitation limit of $1 \mu \mathrm{g} / \mathrm{L}$. 
TABLE C.4 Results of inorganic analyses on groundwater samples collected during the 2004 sampling events at Morrill, Kansas.

\begin{tabular}{|c|c|c|c|c|c|c|c|c|c|c|c|}
\hline \multirow[b]{2}{*}{ Location } & \multirow[b]{2}{*}{ Sample } & \multirow{2}{*}{$\begin{array}{c}\text { Depth } \\
\text { (ft BGL) }\end{array}$} & \multirow{2}{*}{$\begin{array}{c}\text { Sample } \\
\text { Date }\end{array}$} & \multicolumn{8}{|c|}{ Concentration (mg/L) } \\
\hline & & & & Aluminum & Calcium & Chloride & Iron & Magnesium & Manganese & Nitrate & Nitrite \\
\hline MW6S & MRMW-S6-16440/16441 & $10-25$ & $5 / 10 / 04$ & $<0.2$ & 479 & 28.2 & $<0.1$ & 102 & 0.284 & 0.24 & $<0.005$ \\
\hline MW7S & MRMW-S7-16442/16444 & $20-45$ & $5 / 10 / 04$ & $<0.2$ & 106 & 15.6 & $<0.1$ & 21.8 & $<0.015$ & 17.3 & 0.012 \\
\hline MW8S & MRMW-S8-16438/16439 & $10-25$ & $5 / 10 / 04$ & $<0.2$ & 135 & 15.6 & $<0.1$ & 37.8 & 0.0164 & 4.7 & $<0.005$ \\
\hline K. Grimm & MRPRIVKGR-W-16474 & Unk $^{\mathrm{a}-100}$ & $6 / 4 / 04$ & $<0.2$ & 104 & 17.8 & $<0.1$ & 37.7 & $<0.015$ & 11.1 & $<0.005$ \\
\hline Manning & MRPRIVCAI-W-16472 & Unk & $6 / 4 / 04$ & $<0.2$ & 127 & 12.1 & $<0.1$ & 31.4 & $<0.015$ & 17.5 & $<0.005$ \\
\hline R. Grimm & MRPRIVRGRI-W-16477 & Unk & $6 / 4 / 04$ & $<0.2$ & 95.8 & 17.6 & $<0.1$ & 36.7 & $<0.015$ & 12.2 & $<0.005$ \\
\hline Rilinger & MRPRIVRIL-W-16471 & Unk & $6 / 4 / 04$ & $<0.2$ & 542 & 19.6 & $<0.1$ & 48.6 & 0.0207 & 0.348 & $<0.005$ \\
\hline Snyder & MRPRIVSNY-W-16476 & Unk-47 & $6 / 4 / 04$ & $<0.2$ & 344 & 17.5 & $<0.1$ & 39.1 & 0.0157 & 9.51 & 0.0873 \\
\hline Stone & MRPRIVSTON-W-16475 & Unk-43 & $6 / 4 / 04$ & $<0.2$ & 98.2 & 10.9 & $<0.1$ & 17.6 & $<0.015$ & 10.6 & $<0.005$ \\
\hline Moravec & MRPRIVMOR-W-16448 & Unk & $6 / 16 / 04$ & $<0.2$ & 96.1 & 6.3 & $<0.1$ & 21.5 & $<0.015$ & 18.2 & $<0.005$ \\
\hline MW1S & MRMW1S-W-16461 & $11-51$ & $6 / 2 / 04$ & $<0.2$ & 118 & 84.6 & $<0.1$ & 27.5 & $<0.015$ & 11.2 & $<0.005$ \\
\hline MW1D & MRMW1D-W-16458 & $63-88$ & $6 / 2 / 04$ & $<0.2$ & 582 & 18.5 & $<0.1$ & 52 & 0.0328 & $<0.2$ & $<0.005$ \\
\hline MW2S & MRMW2S-W-16459 & $13-53$ & $6 / 2 / 04$ & $<0.2$ & 124 & 17.1 & $<0.1$ & 25.8 & $<0.015$ & 16.2 & $<0.005$ \\
\hline MW3S & MRMW3S-W-16462 & $18-48$ & $6 / 2 / 04$ & $<0.2$ & 92.6 & 3.12 & $<0.1$ & 15.8 & $<0.015$ & 10.1 & $<0.005$ \\
\hline MW4S & MRMW4S-W-16470 & $17-47$ & $6 / 4 / 04$ & $<0.2$ & 86.2 & 10.2 & $<0.1$ & 36.6 & $<0.015$ & 18.9 & $<0.005$ \\
\hline MW5S & MRMW5S-W-16460 & $15-55$ & $6 / 2 / 04$ & $<0.2$ & 106 & 11.7 & $<0.1$ & 30.5 & $<0.015$ & 19.5 & $<0.005$ \\
\hline MW6S & MRMW6S-W-16465 & $10-25$ & $6 / 3 / 04$ & $<0.2$ & 470 & 25.8 & $<0.1$ & 111 & 0.268 & 0.339 & $<0.005$ \\
\hline MW7S & MRMW7S-W-16466 & $20-45$ & $6 / 3 / 04$ & $<0.2$ & 100 & 12.8 & $<0.1$ & 21.9 & $<0.015$ & 16.7 & 0.0089 \\
\hline MW8S & MRMW8S-W-16464 & $10-25$ & $6 / 3 / 04$ & $<0.2$ & 130 & 14.3 & $<0.1$ & 35.2 & $<0.015$ & 5.85 & $<0.005$ \\
\hline
\end{tabular}


TABLE C.4 (Cont.)

\begin{tabular}{|c|c|c|c|c|c|c|c|c|c|c|c|}
\hline \multirow[b]{2}{*}{ Location } & \multirow[b]{2}{*}{ Sample } & \multirow{2}{*}{$\begin{array}{c}\text { Depth } \\
\text { (ft BGL) }\end{array}$} & \multirow{2}{*}{$\begin{array}{c}\text { Sample } \\
\text { Date }\end{array}$} & \multicolumn{8}{|c|}{ Concentration (mg/L) } \\
\hline & & & & Nitrogen & Phosphate & Phosphorus & Potassium & Silicon & Sodium & Sulfate & Zinc \\
\hline MW6S & MRMW-S6-16440/16441 & $10-25$ & $5 / 10 / 04$ & 0.088 & $<0.2$ & $<0.25$ & $<5$ & 9.53 & 33.1 & 1,480 & 0.0287 \\
\hline MW7S & MRMW-S7-16442/16444 & $20-45$ & $5 / 10 / 04$ & 15.8 & 0.34 & $<0.25$ & $<5$ & 7.4 & 24.7 & 26.6 & $<0.02$ \\
\hline MW8S & MRMW-S8-16438/16439 & $10-25$ & $5 / 10 / 04$ & 4.3 & 0.49 & $<0.25$ & $<5$ & 7.64 & 32.4 & 258 & $<0.02$ \\
\hline K. Grimm & MRPRIVKGR-W-16474 & $U_{n k}^{a}-100$ & $6 / 4 / 04$ & 11.7 & $<0.2$ & $<0.25$ & $<5$ & 7.9 & 16.8 & 77.4 & $<0.02$ \\
\hline Manning & MRPRIVCAI-W-16472 & Unk & $6 / 4 / 04$ & 18.3 & $<0.2$ & $<0.25$ & $<5$ & 8.7 & 18.1 & 97.4 & 0.299 \\
\hline R. Grimm & MRPRIVRGRI-W-16477 & Unk & $6 / 4 / 04$ & 12.6 & $<0.2$ & $<0.25$ & $<5$ & 8.05 & 18 & 48.4 & 0.0491 \\
\hline Rilinger & MRPRIVRIL-W-16471 & Unk & $6 / 4 / 04$ & 0.179 & $<0.2$ & $<0.25$ & $<5$ & 8.36 & 26.6 & 1,320 & $<0.02$ \\
\hline Snyder & MRPRIVSNY-W-16476 & Unk-47 & $6 / 4 / 04$ & 10.2 & $<0.2$ & $<0.25$ & $<5$ & 7.57 & 22.6 & 722 & 0.0806 \\
\hline Stone & MRPRIVSTON-W-16475 & Unk-43 & $6 / 4 / 04$ & 11.2 & $<0.2$ & $<0.25$ & $<5$ & 7.87 & 15.6 & 42.2 & 0.0296 \\
\hline Moravec & MRPRIVMOR-W-16448 & Unk & $6 / 16 / 04$ & 18.9 & $<0.2$ & $<0.25$ & $<5$ & 8.92 & 15.4 & 26.1 & 0.0272 \\
\hline MW1S & MRMW1S-W-16461 & $11-51$ & $6 / 2 / 04$ & 11.8 & $<0.2$ & $<0.25$ & $<5$ & 7.86 & 36.4 & 35.1 & $<0.02$ \\
\hline MW1D & MRMW1D-W-16458 & $63-88$ & $6 / 2 / 04$ & $<0.010$ & $<0.2$ & $<0.25$ & $<5$ & 8.43 & 27 & 1,340 & $<0.02$ \\
\hline MW2S & MRMW2S-W-16459 & $13-53$ & $6 / 2 / 04$ & 17.2 & $<0.2$ & $<0.25$ & $<5$ & 9.26 & 20.3 & 61.8 & $<0.02$ \\
\hline MW3S & MRMW3S-W-16462 & $18-48$ & $6 / 2 / 04$ & 10.9 & $<0.2$ & $<0.25$ & $<5$ & 7.7 & 23.5 & 20.6 & $<0.02$ \\
\hline MW4S & MRMW4S-W-16470 & $17-47$ & $6 / 4 / 04$ & 19.3 & $<0.2$ & $<0.25$ & $<5$ & 8.26 & 18.9 & 23.5 & $<0.02$ \\
\hline MW5S & MRMW5S-W-16460 & $15-55$ & $6 / 2 / 04$ & 21 & $<0.2$ & $<0.25$ & $<5$ & 8.32 & 19 & 48.7 & $<0.02$ \\
\hline MW6S & MRMW6S-W-16465 & $10-25$ & $6 / 3 / 04$ & 0.0694 & $<0.2$ & $<0.25$ & $<5$ & 10.4 & 36.5 & 1,280 & $<0.02$ \\
\hline MW7S & MRMW7S-W-16466 & $20-45$ & $6 / 3 / 04$ & 17.6 & $<0.2$ & $<0.25$ & $<5$ & 7.76 & 23.9 & 19.3 & $<0.02$ \\
\hline MW8S & MRMW8S-W-16464 & $10-25$ & $6 / 3 / 04$ & 6.52 & $<0.2$ & $<0.25$ & $<5$ & 8.5 & 30.6 & 163 & $<0.02$ \\
\hline
\end{tabular}

a Unk, unknown depth. 
TABLE C.5 Results of tritium analyses on groundwater samples collected during the 2004 sampling events at Morrill, Kansas.

\begin{tabular}{|c|c|c|c|c|}
\hline Location & Sample & $\begin{array}{c}\text { Depth } \\
\text { (ft BGL) }\end{array}$ & $\begin{array}{c}\text { Sample } \\
\text { Date }\end{array}$ & $\begin{array}{l}\text { Tritium } \\
\text { (TU) }\end{array}$ \\
\hline K. Grimm & MRPRIVKGR-W-16474 & $U_{n k}^{a}-100$ & $6 / 4 / 04$ & $6.12 \pm 0.20$ \\
\hline Manning & MRPRIVCAI-W-16472 & Unk & $6 / 4 / 04$ & $6.39 \pm 0.21$ \\
\hline R. Grimm & MRPRIVRGRI-W-16477 & Unk & $6 / 4 / 04$ & $5.55 \pm 0.18$ \\
\hline Rilinger & MRPRIVRIL-W-16471 & Unk & $6 / 4 / 04$ & $6.68 \pm 0.24$ \\
\hline Snyder & MRPRIVSNY-W-16476 & Unk-47 & $6 / 4 / 04$ & $6.34 \pm 0.21$ \\
\hline Stone & MRPRIVSTON-W-16475 & Unk-43 & $6 / 4 / 04$ & $8.02 \pm 0.26$ \\
\hline Moravec & MRPRIVMOR-W-16456 & Unk & $6 / 16 / 04$ & $6.54 \pm 0.22$ \\
\hline MW1S & MRMW1S-W-16461 & $11-51$ & $6 / 2 / 04$ & $6.92 \pm 0.23$ \\
\hline MW1D & MRMW1D-W-16458 & $63-88$ & $6 / 2 / 04$ & $5.84 \pm 0.19$ \\
\hline MW2S & MRMW2S-W-16459 & $13-53$ & $6 / 2 / 04$ & $5.81 \pm 0.19$ \\
\hline MW3S & MRMW3S-W-16462 & $18-48$ & $6 / 2 / 04$ & $6.96 \pm 0.23$ \\
\hline MW4S & MRMW4S-W-16470 & $17-47$ & $6 / 4 / 04$ & $6.33 \pm 0.21$ \\
\hline MW5S & MRMW5S-W-16460 & $15-55$ & $6 / 2 / 04$ & $6.22 \pm 0.21$ \\
\hline MW6S & MRMW6S-W-16465 & $10-25$ & $6 / 3 / 04$ & $0.22 \pm 0.09$ \\
\hline MW7S & MRMW7S-W-16466 & $20-45$ & $6 / 3 / 04$ & $7.44 \pm 0.25$ \\
\hline MW8S & MRMW8S-W-16464 & $10-25$ & $6 / 3 / 04$ & $2.68 \pm 0.10$ \\
\hline
\end{tabular}

a Unk, unknown depth. 


\section{Appendix D:}

\section{Water Level Data}


TABLE D.1 Water levels measured by hand during the 2004 sampling events at Morrill, Kansas.

\begin{tabular}{|c|c|c|c|c|c|c|c|c|}
\hline \multirow[b]{3}{*}{ Well } & \multirow{2}{*}{\multicolumn{2}{|c|}{ Elevation (ft AMSL) }} & \multirow{2}{*}{\multicolumn{2}{|c|}{ Depth (ft BGL) }} & \multirow{2}{*}{\multicolumn{2}{|c|}{ Measurement }} & \multicolumn{2}{|c|}{ Water Level } \\
\hline & & & & & & & \multirow{2}{*}{$\begin{array}{c}\text { Depth } \\
\text { (ft BGL) }\end{array}$} & \multirow{2}{*}{$\begin{array}{l}\text { Elevation } \\
\text { (ft AMSL) }\end{array}$} \\
\hline & Ground Surface & Reference $^{a}$ & Well & Screen Interval & Date & Time & & \\
\hline MW1S & 1122.3 & 1124.68 & 51 & $11-51$ & $7 / 15 / 04$ & $14: 09$ & 27.37 & 1097.31 \\
\hline MW1D & 1122.2 & 1124.63 & 88 & $63-88$ & $7 / 15 / 04$ & $14: 24$ & 27.40 & 1097.23 \\
\hline MW2S & 1137.3 & 1137.07 & 53 & $13-53$ & $7 / 15 / 04$ & $13: 05$ & 37.11 & 1099.96 \\
\hline MW3S & 1136.0 & 1135.76 & 48 & $18-48$ & $7 / 15 / 04$ & $12: 24$ & 31.18 & 1104.58 \\
\hline MW4S & 1143.8 & 1143.61 & 47 & $17-47$ & $7 / 15 / 04$ & $11: 16$ & 42.88 & 1100.73 \\
\hline MW5S & 1122.4 & 1122.21 & 55 & $15-55$ & $7 / 15 / 04$ & $13: 34$ & 26.20 & 1096.01 \\
\hline MW6S & 1091.4 & 1090.97 & 27 & $10-25$ & $7 / 15 / 04$ & $15: 50$ & 4.45 & 1086.52 \\
\hline MW7S & 1120.4 & 1119.86 & 47 & $20-45$ & $7 / 15 / 04$ & $14: 43$ & 21.63 & 1098.23 \\
\hline MW8S & 1099.0 & 1098.53 & 27 & $10-25$ & $7 / 15 / 04$ & $15: 13$ & 4.84 & 1093.69 \\
\hline
\end{tabular}

a Reference point for measuring water level depth. 


\section{Appendix E:}

\section{Quality Control for Sample Collection,} Handling, and Analysis 


\section{Appendix E:}

\section{Quality Control for Sample Collection, Handling, and Analysis}

Groundwater sampling was conducted at Morrill, Kansas, in February and June-August, 2004 to complete the scope of work presented in the Phase I Work Plan (Argonne 2003b) and supplement the data presented in the Phase I-II Interim Report (Argonne 2004a). The quality assurance/quality control (QA/QC) procedures for sample collection, handling, and analysis are described in detail in the Master Work Plan (Argonne 2002) and the Phase I Work Plan (Argonne 2003b). Evaluation of the organic analytical data was consistent with the USEPA National Functional Guidelines for Organic Data Review (EPA 1994).

\section{E.1 Sampling to Monitor Sampling Collection, Handling, and Analysis Procedures}

Sample collection and handling activities were monitored by the documentation of samples as they were collected and the use of chain-of-custody (COC) forms and custody seals to ensure sample integrity during the handling and shipment of samples for analysis. QA/QC samples collected included a field blank, equipment rinsates, and trip blanks. Blind field replicate samples were collected, and samples were selected for duplicate analysis as a measure of analytical precision. The QA/QC samples are listed in Table E.1. Analytical results for carbon tetrachloride and chloroform in QA/QC samples collected to monitor sample collection and handling activities are in Table E.2.

\section{E.1.1 Field Blank}

A blank of the water used during the investigation was free of contamination.

\section{E.1.2 Equipment Rinsates}

Rinsate samples were collected to ensure that decontamination procedures were adequate to prevent cross-contamination of samples during collection. Neither carbon tetrachloride nor chloroform was detected in the rinsate samples. 


\section{E.1.3 Trip Blanks}

Trip blanks were prepared and included in shipments of water samples for organic analysis as an indicator of cross-contamination of samples during shipment. Neither carbon tetrachloride nor chloroform was detected in the trip blanks.

\section{E.1.4 Replicate Samples/Duplicate Analyses}

As an indicator of the consistency of the sampling methodology followed and to provide a measure of analytical precision, blind replicate groundwater samples were collected. In addition, samples were selected by the AGEM Laboratory for duplicate organic analysis. Selected samples were shipped to a second laboratory for verification analysis. Blind replicate samples, samples selected for duplicate analysis, and samples selected for verification organic analysis are listed in Table E.1.

\section{E.2 Quality Control for Organic Analysis of Water Samples}

Eighteen groundwater samples were collected for organic analysis (Table C.3, Appendix C). These samples and the associated QC samples, including five blind field replicates, were shipped immediately to the AGEM Laboratory for analysis using EPA Method 524.2. To verify accuracy of the analytical results obtained using EPA Method 524.2, duplicate (split) samples were collected for verification analysis at Envirosystems, Inc., Columbia, Maryland, using CLP methodology (EPA 1989). Based on the results obtained by the AGEM Laboratory, selected duplicate samples were subjected to verification analysis.

The following sections describe QC measures followed during analysis of the water samples and the quality of the organic analytical data from each laboratory. Analytical data from the AGEM Laboratory are discussed in Section E.2.1, and analytical data from Envirosystems, Inc., are discussed in Section E.2.2. A comparison of the analytical results from the AGEM Laboratory and Envirosystems, Inc., is presented in Section E.2.3. 


\section{E.2.1 Organic Analysis of Water Samples at AGEM Laboratory}

Water samples shipped to the AGEM Laboratory were analyzed by the purge-and-trap method with a gas chromatograph-mass spectrometer (GC-MS) system. For the purge-and-trap analyses, VOCs present in the groundwater sample were extracted (purged) from the sample matrix by bubbling an inert gas through the sample. The purged components were trapped in a specified sorbent tube. After the purging, the sorbent tube was heated and back-flushed with an inert gas to desorb the components into the GC-MS system. The compounds eluting from the GC column were identified by retention time and by comparison with reference library spectra. The concentration of each component was calculated by comparison of the mass spectrometer response for the quantitation ion to the response for corresponding calibration curves and/or internal standards.

Water samples submitted to the AGEM Laboratory for organic analysis were analyzed in seven sample delivery groups (SDGs). Table E.3 identifies the groundwater and associated QC samples analyzed in each SDG. The QA/QC procedures followed included analysis of instrument calibration check standards, the analysis of laboratory blanks, monitoring of surrogate spike recovery, and duplicate laboratory analyses. Significant results include the following:

- Samples shipped to the AGEM Laboratory were received with custody seals intact and at appropriate temperature. All samples were analyzed within required holding times.

- Contaminants of concern were not detected in laboratory method blanks analyzed with the samples.

- For each SDG, analytical instrument calibration was monitored by the analysis of calibration check standards. Table E.3 shows the relative percent difference (RPD) between the known and calculated concentrations of the standards. With one exception, the concentrations of calibration check standards measured in each SDG were within $\pm 20 \%$. The RPD for the calibration standard analyzed with SDG $04-2-21$ at $21 \%$ is accepted without qualification of the associated samples.

- Surrogate standard determinations were performed on samples and blanks by using surrogate spike compounds fluorobenzene, 1,2-dichlorobenzene- $\mathrm{d}_{4}$, and 
4-bromofluorobenzene. Table E.3 shows the percent recovery of these systemmonitoring compounds for each of the analyses. With two exceptions, the surrogate recoveries were within the QC limit of $80-120 \%$ for all samples in the initial analysis or a successful re-analysis.

- The recovery of spike compound fluorobenzene at $121 \%$ in the analysis of the calibration standard associated with SDG 04-6-7 did not inhibit detection of contamination in the samples and is accepted without qualification.

- Low recovery of spike compounds fluorobenzene at $78 \%$ and 4-bromofluorobenzene at $79 \%$ in the analysis of trip blank MRPRIVMORW-16457 in SDG 04-6-17 also does not warrant qualification. The trip blank was shipped with private well sample MRPRIVMOR-W-16456 collected on June 16, 2004. Both the sample and trip blank were free of contamination, indicating that cross-contamination of the associated sample did not occur.

- As a measure of the consistency in the sampling and analytical methodologies, five blind replicate groundwater samples were collected for organic analysis and one sample was selected by the laboratory for duplicate analysis. Table E.4 summarizes the analytical results for the initial samples and their associated secondary analyses. Agreement is excellent, indicating consistency in both the sampling and analytical methodologies. The RPD values between the primary and secondary analyses were $0-34.2 \%$, with an average RPD of $7.2 \%$.

The analytical data from the AGEM Laboratory is acceptable for quantitative determination of contaminant distribution in groundwater.

\section{E.2.2 Organic Analysis of Water Samples by Envirosystems, Inc.}

In accordance with the QA/QC procedures defined in the Master Work Plan (Argonne 2002), the analyses of water samples at the AGEM Laboratory with EPA Method 524.2 were verified by using EPA-defined CLP methodology. Based on the results determined by the AGEM Laboratory, selected replicate samples (identified in Table E.1) were then analyzed. A 
comparison of the AGEM Laboratory and CLP analytical results for the replicate samples is provided in Section E.2.3. Below is a discussion of the quality of the CLP organic analytical data.

Four replicate groundwater samples were shipped to Envirosystems, Inc., for organic analysis with CLP methodology. The samples were sent in one shipment with a trip blank. A complete CLP data package was provided. The QA/QC procedures followed in the CLP analysis included initial and continuing calibration of instruments, the analysis of laboratory blanks, monitoring of surrogate spike recovery, and matrix spike/matrix spike duplicate analyses. Significant results include the following:

- Samples shipped to the CLP laboratory were received with custody seals intact and at acceptable temperature. All samples were analyzed within required holding times.

- Analytical instruments were properly tuned; initial and continuing calibration checks remained within the allowable limit.

- The trip blank was free of contamination. Methylene chloride was present at low concentration $(1 \mu \mathrm{g} / \mathrm{L})$ in the laboratory blank.

- Surrogate standard determinations were performed on samples and blanks using the surrogate spike compounds toluene- $\mathrm{d}_{8}$, 4-bromofluorobenzene, and 1,2-dichloroethane- $\mathrm{d}_{4}$. Table E.5 shows the percent recovery of the systemmonitoring compounds for each of the CLP analyses. Recovery of the surrogate spikes was within the acceptable range (identified in Table E.5) specific to each surrogate for all analyses.

- A matrix spike/matrix spike duplicate analysis was performed in accordance with CLP protocol by using matrix spike compounds 1,1-dichloroethene, trichloroethene, chlorobenzene, toluene, and benzene to evaluate the matrix effect of samples on the analytical methodology. Table E.6 shows the percent recovery of each spike compound in the spike/spike duplicate analysis, as well as the calculated RPD values between the analytical results. QC limits were met for the analyses. 
Organic analytical data from Envirosystems, Inc., for the replicate groundwater samples are acceptable for comparison to AGEM Laboratory data.

\section{E.2.3 Verification Organic Analysis of Water Samples}

In accordance with the QA/QC procedures defined in the Master Work Plan (Argonne 2002), selected replicates of the water samples analyzed at the AGEM Laboratory with EPA Method 524.2 were subjected to verification analysis using EPA-defined CLP methodology. Four groundwater samples (22\% of the groundwater samples) analyzed at the AGEM Laboratory were also analyzed with CLP methodology. Table E.7 compares the carbon tetrachloride and chloroform analytical results obtained using EPA Method 524.2 and CLP methodology.

Analytical results for water samples analyzed at the AGEM Laboratory using EPA Method 524.2 are supported by the analytical results for replicate samples analyzed by Envirosystems, Inc., with EPA CLP methodology. Samples analyzed at AGEM Laboratory with no detection of carbon tetrachloride and/or chloroform were analyzed by Envirosystems, Inc., with similar results. For samples in which carbon tetrachloride and/or chloroform were present, the RPD values between the concentrations reported by the two laboratories were 5.2-47\%, for an average RPD of $26 \%$. Methylene chloride, detected by Envirosystems, Inc., in sample MRMW1D-W-16458 and in the associated blank at a concentration of $1 \mu \mathrm{g} / \mathrm{L}$, was not detected by AGEM Laboratory and is not reported.

\section{E.3 Quality Control for Inorganic Analyses of Groundwater Samples}

Groundwater samples were collected for inorganic analysis to aid in geochemical characterization of the water-bearing zone. Groundwater samples collected for inorganic analysis were shipped immediately to Severn-Trent Laboratory for filtration and analysis. The analyses included dissolved anion concentrations (chloride, sulfate, nitrate, and phosphate) using EPA Method 300, nitrite nitrogen using EPA Method 354.1, nitrate/nitrite nitrogen using EPA Method 353.2, and dissolved metals (aluminum, calcium, iron, magnesium, manganese, phosphorus, potassium, silicon, sodium, and zinc) using EPA Method 6010.

Inorganic analysis of the groundwater samples was conducted in four SDGs. The QA/QC procedures followed included instrument calibration through analysis of spiked calibration check 
standards, verification of interelement and background correction factors through the analysis of inductively coupled plasma (ICP) interference check samples, the analysis of QC samples, and the duplicate analysis of selected samples. Significant points are the following:

- Initial and continuing calibration of analytical equipment was verified according to method protocol by the analysis of instrument check standards to determine instrument drift. Accuracy was measured by the percent recovery of known concentrations of the metals and anions of concern added to the calibration check standards.

- Interelement and background correction factors for ICP analysis were determined through the analysis of ICP interference check samples, with results falling within the control limit of $\pm 20 \%$ of the established mean value for each SDG.

- Accuracy in the analytical methodology followed was measured by the analysis of laboratory control samples with each SDG. The recovery of known concentrations of the metals and anions of concern in spiked laboratory control samples, shown in Table E.8, was within the desired range of 80$120 \%$. Good precision is indicated by the low RPD values between the initial and secondary analyses.

- Good precision is also indicated by the low RPD values between three samples and replicates collected during the investigation, shown in Table E.9.

The inorganic results for groundwater samples from Severn-Trent Laboratory are acceptable for geochemical characterization based on the recovery of known concentrations of the analytes of concern in a QC samples analyzed with the groundwater samples and relative percent difference in duplicate analyses.

\section{E.4 Quality Control for Tritium Analyses of Groundwater Samples}

Groundwater samples collected were analyzed for tritium at the University of Miami Tritium Laboratory in Miami, Florida. Tritium concentrations were reported on the basis of the U.S. National Institute of Science and Technology tritium water standard \#4926 as measured on 
September 3, 1961, and again on September 3, 1978, with a half-life of 12.32 years. Concentrations were reported in tritium units (TU), equivalent to 3.193 picocuries per kilogram of water. Because counting efficiency and background concentration are different for each instrument, the reported concentrations were corrected for cosmic intensity and gas pressure. Typical efficiencies are equivalent to 1 count per minute (cpm) per TU. Background is about $0.3 \mathrm{cpm}$, known to $\pm 0.02 \mathrm{cpm}$. Good precision in the tritium results is indicated by an RPD of $0.3 \%$ between the sample and replicate from monitoring well MW1S. The tritium analytical data are accepted for age-dating of groundwater. 
TABLE E.1 Quality control samples collected during the 2004 sampling events at Morrill, Kansas.

\begin{tabular}{lcc}
\hline Socation & Depth & Sample \\
(ft BGL) & Date & Sample Description \\
\hline
\end{tabular}

Field blank

QC $\quad$ MRQCFB-W-16469

$-$

Equipment rinsates

QC MRQCRI-W-16468

QC MRQCRI-W-16497

Trip blanks

QC

MRTB-W-16501

QC MRQCTB-W-16463

QC MRQCTB-W-16496

QC MR-TB-W-18000

QC MRPRIVMOR-W-16457

QC MR-W-Trip Blank

QC

CNQCTB-W-16160

Blind replicate groundwater samples

$\begin{array}{llcl}\text { Isch } & \text { MRJR-W-16503 } & \text { Unk } & \\ \text { Isch } & \text { MRJR-W-16504 } & \text { Unk } & 02 / 19 / 04 \\ \text { MW7S } & \text { MRMW-S7-16443/ } & 20-45 & 02 / 19 / 04 \\ & 16445 & & \\ & & & \\ \text { MW1S } & \text { MRQCDU-W-16467 } & 11-51 & 06 / 02 / 04 \\ & & & \\ \text { Manning } & \text { MRQCDU-W-16473 } & \text { Unk } & 06 / 04 / 04 \\ \text { Allen } & \text { MRQCDU-W-16506 } & \text { Unk } & 08 / 27 / 0\end{array}$

$-\quad 06 / 05 / 04$

- $\quad 06 / 08 / 04$

- $\quad 06 / 16 / 04$

$-\quad 7 / 13 / 04$
06/03/04 Field blank of water used for equipment decontamination during sampling in June 2004.

- $\quad$ 06/03/04 Rinsate of decontaminated Redi-Flo sampling tube used during sampling of MW7S.

_ 06/04/04 Rinsate of decontaminated Redi-Flo pump prior to sampling of Snyder well.

$-\quad 02 / 19 / 04$

- $\quad 06 / 02 / 04$

$-\quad 08 / 28 / 04$

Trip blank sent to the AGEM Laboratory for organic analysis with Isch well samples listed on COC 3027.

Trip blank sent to the AGEM Laboratory with samples listed on COC 3421.

Trip blank sent to the AGEM Laboratory with samples listed on COC 3674.

Trip blank sent to Envirosystems, Inc., for verification organic analysis with samples listed on COC 4010.

Trip blank sent to the AGEM Laboratory with sample listed on COC 3026.

Trip blank sent to the AGEM Laboratory for organic analysis with waste purge water sample listed on COC 725.

rip blank sent to the AGEM Laboratory for organic analysis with private well sample listed on COC 1616.

Replicate of sample Isch well sample MRJR-W-16502 for organic analysis.

Second replicate of Isch well sample MRJR-W-16502 for organic analysis.

Replicate of monitoring well sample MRMW-S7-16442/16444 for inorganics analysis.

Sample 16443 was used for anions analysis. Sample 16445 was used for cations analysis.

Replicate of monitoring well sample MRMW1S-W-16461 for organic, inorganic, and tritium analysis.

Replicate of private well sample MRPRIVCAI-W-16472 for organic and inorganic analysis. Replicate of private well sample MRALLEN-W-16505 for organic analysis.

Sample selected by AGEM Laboratory for duplicate organic analysis

MW7S MRMW7S-W16466DUP

20-45

06/03/04 
TABLE E.1 (Cont.)

\begin{tabular}{|c|c|c|c|c|}
\hline Location & Sample & $\begin{array}{l}\text { Depth } \\
\text { (ft BGL) }\end{array}$ & $\begin{array}{l}\text { Sample } \\
\text { Date }\end{array}$ & Sample Description \\
\hline \multicolumn{5}{|c|}{ Samples selected for verification organic analysis at Envirosystems, Inc. } \\
\hline $\begin{array}{l}\text { Stone } \\
\text { MW1D } \\
\text { MW3S } \\
\text { MW7S }\end{array}$ & $\begin{array}{l}\text { MRPRIVSTON-W-16475 } \\
\text { MRMW1D-W-16458 } \\
\text { MRMW3S-W-16462 } \\
\text { MRMW7S-W-16466 }\end{array}$ & $\begin{array}{l}\text { Unk-43 } \\
63-88 \\
18-48 \\
20-45\end{array}$ & $\begin{array}{l}6 / 4 / 04 \\
6 / 2 / 04 \\
6 / 2 / 04 \\
6 / 3 / 04\end{array}$ & $\begin{array}{l}\text { Private well sample. } \\
\text { Monitoring well sample. } \\
\text { Monitoring well sample. } \\
\text { Monitoring well sample. }\end{array}$ \\
\hline \multicolumn{5}{|c|}{ Waste characterization sample } \\
\hline QC & MR-W-16478 & - & $7 / 13 / 04$ & Waste equipment decontamination water. \\
\hline
\end{tabular}

a Unk, unknown depth. 
TABLE E.2 Carbon tetrachloride and chloroform analytical results for samples collected to monitor sample collection and handling activities.

\begin{tabular}{|c|c|c|c|c|}
\hline \multirow[b]{2}{*}{ Sample } & \multirow[b]{2}{*}{$\begin{array}{l}\text { Sample } \\
\text { Date }\end{array}$} & \multicolumn{3}{|c|}{ Concentration ( $\mu \mathrm{g} / \mathrm{L}$ in water) } \\
\hline & & $\begin{array}{c}\text { Carbon } \\
\text { Tetrachloride }\end{array}$ & Chloroform & $\begin{array}{c}\text { Quantitation } \\
\text { Limit }\end{array}$ \\
\hline \multicolumn{5}{|l|}{ Field blank } \\
\hline MRQCFB-W-16469 & $6 / 3 / 04$ & $N D^{a}$ & ND & 1 \\
\hline \multicolumn{5}{|l|}{ Equipment rinsates } \\
\hline $\begin{array}{l}\text { MRQCRI-W-16468 } \\
\text { MRQCRI-W-16497 }\end{array}$ & $\begin{array}{l}6 / 3 / 04 \\
6 / 4 / 04\end{array}$ & $\begin{array}{l}\text { ND } \\
\text { ND }\end{array}$ & $\begin{array}{l}\text { ND } \\
\text { ND }\end{array}$ & $\begin{array}{l}1 \\
1\end{array}$ \\
\hline \multicolumn{5}{|l|}{ Trip blanks } \\
\hline $\begin{array}{l}\text { MRTB-W-16501 } \\
\text { MRQCTB-W-16463 } \\
\text { MRQCTB-W-16496 } \\
\text { MR-TB-W-18000 } \\
\text { MRPRIVMOR-W-16457 } \\
\text { MR-W-trip blank } \\
\text { CNQCTB-W-16160 }\end{array}$ & $\begin{array}{r}2 / 19 / 04 \\
6 / 2 / 04 \\
6 / 5 / 04 \\
6 / 8 / 04 \\
6 / 16 / 04 \\
7 / 13 / 04 \\
8 / 27 / 04\end{array}$ & $\begin{array}{l}\text { ND } \\
\text { ND } \\
\text { ND } \\
\text { ND } \\
\text { ND } \\
\text { ND } \\
\text { ND }\end{array}$ & $\begin{array}{l}\text { ND } \\
\text { ND } \\
\text { ND } \\
\text { ND } \\
\text { ND } \\
\text { ND } \\
\text { ND }\end{array}$ & $\begin{array}{l}1 \\
1 \\
1 \\
5 \\
1 \\
1 \\
1\end{array}$ \\
\hline \multicolumn{5}{|l|}{ Waste characterization } \\
\hline MR-W-16478 & $7 / 13 / 04$ & ND & ND & 1 \\
\hline
\end{tabular}

a ND, contaminant not detected at the quantitation limit indicated. 
TABLE E.3 Results of organic analyses on quality control samples collected to monitor water analyses at the AGEM Laboratory by the purge-and-trap method.

\begin{tabular}{|c|c|c|c|c|c|c|c|}
\hline \multirow[b]{3}{*}{ Sample } & \multirow{2}{*}{\multicolumn{3}{|c|}{ Recovery of Surrogate Compounds ${ }^{a}(\%)$}} & \multicolumn{4}{|c|}{$\begin{array}{l}\text { Measured Values for Calibration } \\
\text { Check Standards }\end{array}$} \\
\hline & & & & \multicolumn{2}{|c|}{ Carbon Tetrachloride } & \multicolumn{2}{|c|}{ Chloroform } \\
\hline & Fluorobenzene & $\begin{array}{l}\text { 1,2-Dichloro- } \\
\text { benzene- } d_{4}\end{array}$ & $\begin{array}{l}\text { 4-Bromo- } \\
\text { fluorobenzene }\end{array}$ & $\begin{array}{l}\text { Concentration } \\
(\mu \mathrm{g} / \mathrm{L})\end{array}$ & $\mathrm{RPD}^{\mathrm{b}}$ & $\begin{array}{l}\text { Concentration } \\
(\mu \mathrm{g} / \mathrm{L})\end{array}$ & $\mathrm{RPD}^{\mathrm{b}}$ \\
\hline \multicolumn{8}{|c|}{ SDG 04-2-21, analysis date February 21, 2004} \\
\hline $20 \mu \mathrm{g} / \mathrm{L}$ standard & 101 & 100 & 105 & 17.39 & 13.9 & 16.04 & $21^{c}$ \\
\hline Laboratory blank & 100 & 100 & 100 & & & & \\
\hline $\begin{array}{l}\text { MRJR-W-16502 } \\
\text { MRJR-W-16503 } \\
\text { MRJR-W-16504 } \\
\text { MRTB-W-16501 }\end{array}$ & $\begin{array}{l}94 \\
97 \\
90 \\
87\end{array}$ & $\begin{array}{l}93 \\
96 \\
88 \\
81\end{array}$ & $\begin{array}{l}90 \\
96 \\
88 \\
81\end{array}$ & & & & \\
\hline \multicolumn{8}{|c|}{ SDG 04-6-4, analysis date June 4, 2004} \\
\hline $\begin{array}{l}20 \mu \mathrm{g} / \mathrm{L} \text { standard } \\
\text { Laboratory blank }\end{array}$ & $\begin{array}{l}104 \\
115\end{array}$ & $\begin{array}{l}111 \\
116\end{array}$ & $\begin{array}{l}110 \\
118\end{array}$ & 19.5 & 2.5 & 21.86 & 8.9 \\
\hline $\begin{array}{l}\text { MRMW1S-W-16461 } \\
\text { MRMW2S-W-16459 } \\
\text { MRMW1D-W-16458 } \\
\text { MRQCDU-W-16467 } \\
\text { MRMW3S-W-16462 } \\
\text { MRMW8S-W-16464 } \\
\text { MRMW7S-W-16466 } \\
\text { MRMW7S-W-16466DUP } \\
\text { Laboratory blank } \\
\text { MRMW5S-W-16460 } \\
\text { MRMW6S-W-16465 } \\
\text { MRQCRI-W-16468 } \\
\text { MRQCTB-W-16463 } \\
\text { MRQCFB-W-16469 }\end{array}$ & $\begin{array}{l}92 \\
95 \\
97 \\
92 \\
89 \\
90 \\
92 \\
89 \\
85 \\
86 \\
97 \\
94 \\
83 \\
89\end{array}$ & $\begin{array}{r}95 \\
107 \\
105 \\
102 \\
96 \\
97 \\
96 \\
92 \\
84 \\
91 \\
103 \\
95 \\
88 \\
94\end{array}$ & $\begin{array}{l}91 \\
99 \\
98 \\
95 \\
90 \\
92 \\
95 \\
90 \\
82 \\
88 \\
98 \\
90 \\
84 \\
90\end{array}$ & & & & \\
\hline
\end{tabular}




\begin{tabular}{|c|c|c|c|c|c|c|c|}
\hline \multirow[b]{3}{*}{ Sample } & \multirow{2}{*}{\multicolumn{3}{|c|}{ Recovery of Surrogate Compounds ${ }^{a}(\%)$}} & \multicolumn{4}{|c|}{$\begin{array}{c}\text { Measured Values for Calibration } \\
\text { Check Standards }\end{array}$} \\
\hline & & & & \multicolumn{2}{|c|}{ Carbon Tetrachloride } & \multicolumn{2}{|c|}{ Chloroform } \\
\hline & Fluorobenzene & $\begin{array}{l}\text { 1,2-Dichloro- } \\
\text { benzene- } d_{4}\end{array}$ & $\begin{array}{l}\text { 4-Bromo- } \\
\text { fluorobenzene }\end{array}$ & $\begin{array}{l}\text { Concentration } \\
(\mu \mathrm{g} / \mathrm{L})\end{array}$ & $\mathrm{RPD}^{\mathrm{b}}$ & $\begin{array}{l}\text { Concentration } \\
(\mu \mathrm{g} / \mathrm{L})\end{array}$ & $\mathrm{RPD}^{\mathrm{b}}$ \\
\hline \multicolumn{8}{|c|}{ SDG 04-6-7, analysis date June 7, 2004} \\
\hline $\begin{array}{l}20 \mu \mathrm{g} / \mathrm{L} \text { standard } \\
\text { Laboratory blank }\end{array}$ & $\begin{array}{l}121^{\mathrm{c}} \\
105\end{array}$ & $\begin{array}{l}102 \\
101\end{array}$ & $\begin{array}{l}111 \\
100\end{array}$ & 18.7 & 6.7 & 19.51 & 2.5 \\
\hline $\begin{array}{l}\text { MRMW4S-W-16470 } \\
\text { MRPRIVRIL-W-16471 } \\
\text { MRPRIVSTON-W-16475 } \\
\text { MRPRIVCAI-W-16472 } \\
\text { MRQCDU-W-16473 } \\
\text { MRPRIVKGR-W-16474 } \\
\text { MRPRIVSNY-W-16476 } \\
\text { MRPRIVRGRI-W-16477 } \\
\text { MRQCRI-W-16497 } \\
\text { MRQCTB-W-16496 }\end{array}$ & $\begin{array}{c}109 \\
52^{\mathrm{c}} \\
89 \\
97 \\
77^{\mathrm{c}} \\
75^{\mathrm{c}} \\
105 \\
101 \\
106 \\
93\end{array}$ & $\begin{array}{c}106 \\
56^{c} \\
84 \\
99 \\
89 \\
81 \\
104 \\
103 \\
107 \\
98\end{array}$ & $\begin{array}{c}104 \\
54^{\mathrm{c}} \\
85 \\
96 \\
79^{\mathrm{c}} \\
75^{\mathrm{c}} \\
102 \\
103 \\
107 \\
94\end{array}$ & $\begin{array}{l}\text { Reanalyzed in St } \\
\text { Reanalyzed in St }\end{array}$ & G $04-6-8$ & & \\
\hline \multicolumn{8}{|c|}{ SDG 04-6-8, analysis date June 8, 2004} \\
\hline $\begin{array}{l}20 \mu \mathrm{g} / \mathrm{L} \text { standard } \\
\text { Laboratory blank }\end{array}$ & $\begin{array}{r}100 \\
94\end{array}$ & $\begin{array}{r}100 \\
99\end{array}$ & $\begin{array}{r}100 \\
95\end{array}$ & 20.66 & 3.2 & 19.66 & 1.7 \\
\hline $\begin{array}{l}\text { MRPRIVRIL-W-16471 } \\
\text { MRQCDU-W-16473 } \\
\text { MRPRIVKGR-W-16474 }\end{array}$ & $\begin{array}{l}119 \\
102 \\
103\end{array}$ & $\begin{array}{l}110 \\
102 \\
105\end{array}$ & $\begin{array}{l}115 \\
105 \\
108\end{array}$ & & & & \\
\hline \multicolumn{8}{|c|}{ SDG 04-6-17, analysis date June 17, 2004} \\
\hline $\begin{array}{l}20 \mu \mathrm{g} / \mathrm{L} \text { standard } \\
\text { Laboratory blank }\end{array}$ & $\begin{array}{r}95 \\
100\end{array}$ & $\begin{array}{l}103 \\
100\end{array}$ & $\begin{array}{r}91 \\
100\end{array}$ & 19.74 & 1.3 & 17.69 & 12.2 \\
\hline $\begin{array}{l}\text { MRPRIVMOR-W-16456 } \\
\text { MRPRIVMOR-W-16457 }\end{array}$ & $\begin{array}{l}99 \\
78^{\mathrm{c}}\end{array}$ & $\begin{array}{r}105 \\
90\end{array}$ & $\begin{array}{l}98 \\
79^{c}\end{array}$ & Accepted. Trip b & ank with ur & contaminated sa & nple. \\
\hline
\end{tabular}




\begin{tabular}{|c|c|c|c|c|c|c|c|}
\hline \multirow[b]{3}{*}{ Sample } & \multirow{2}{*}{\multicolumn{3}{|c|}{ Recovery of Surrogate Compounds ${ }^{a}(\%)$}} & \multicolumn{4}{|c|}{$\begin{array}{l}\text { Measured Values for Calibration } \\
\text { Check Standards }\end{array}$} \\
\hline & & & & \multicolumn{2}{|c|}{ Carbon Tetrachloride } & \multicolumn{2}{|c|}{ Chloroform } \\
\hline & Fluorobenzene & $\begin{array}{l}\text { 1,2-Dichloro- } \\
\text { benzene- } d_{4}\end{array}$ & $\begin{array}{l}\text { 4-Bromo- } \\
\text { fluorobenzene }\end{array}$ & $\begin{array}{l}\text { Concentration } \\
(\mu \mathrm{g} / \mathrm{L})\end{array}$ & $\mathrm{RPD}^{\mathrm{b}}$ & $\begin{array}{l}\text { Concentration } \\
(\mu \mathrm{g} / \mathrm{L})\end{array}$ & $\mathrm{RPD}^{\mathrm{b}}$ \\
\hline \multicolumn{8}{|c|}{ SDG 04-7-14, analysis date July 14, 2004} \\
\hline $\begin{array}{l}20 \mu \mathrm{g} / \mathrm{L} \text { standard } \\
\text { Laboratory blank }\end{array}$ & $\begin{array}{l}102 \\
100\end{array}$ & $\begin{array}{l}102 \\
100\end{array}$ & $\begin{array}{r}87 \\
100\end{array}$ & 18.97 & 5.3 & 18.65 & 6.9 \\
\hline $\begin{array}{l}\text { MR-W-16478 } \\
\text { MR-W-Trip Blank }\end{array}$ & $\begin{array}{l}97 \\
99\end{array}$ & $\begin{array}{l}94 \\
97\end{array}$ & $\begin{array}{l}95 \\
97\end{array}$ & & & & \\
\hline \multicolumn{8}{|c|}{ SDG 04-8-27 analysis date August 27, 2004} \\
\hline $\begin{array}{l}20 \mu \mathrm{g} / \mathrm{L} \text { standard } \\
\text { Laboratory blank }\end{array}$ & $\begin{array}{r}89 \\
100\end{array}$ & $\begin{array}{r}84 \\
100\end{array}$ & $\begin{array}{r}88 \\
100\end{array}$ & 16.24 & 20 & 18.54 & 7.5 \\
\hline $\begin{array}{l}\text { MRALLEN-W-16505 } \\
\text { MRQCDU-W-16506 } \\
\text { CNQCTB-W-16160 }\end{array}$ & $\begin{array}{l}93 \\
97 \\
82\end{array}$ & $\begin{array}{l}93 \\
98 \\
83\end{array}$ & $\begin{array}{l}94 \\
99 \\
84\end{array}$ & & & & \\
\hline
\end{tabular}

a Quality control limits for recovery of surrogate compounds: 80-120\%.

b Quality control limits for RPD for calibration check standards: $\pm 20 \%$.

c Surrogate recovery outside the quality control limit. 
Monitoring Well Installation and Sampling, Morrill, Kansas

TABLE E.4 Carbon tetrachloride and chloroform results for initial and secondary quality control organic analyses at the AGEM Laboratory with EPA Method 524.2.

\begin{tabular}{|c|c|c|c|c|c|c|}
\hline \multirow[b]{2}{*}{ Location } & \multirow[b]{2}{*}{$\begin{array}{l}\text { Depth } \\
\text { (ft BGL) }\end{array}$} & \multirow[b]{2}{*}{$\begin{array}{l}\text { Sample } \\
\text { Date }\end{array}$} & \multirow[b]{2}{*}{ Sample } & \multirow[b]{2}{*}{ Analysis } & \multicolumn{2}{|c|}{ Concentration $(\mu \mathrm{g} / \mathrm{L})$} \\
\hline & & & & & $\begin{array}{l}\text { Carbon } \\
\text { Tetrachloride }\end{array}$ & Chloroform \\
\hline Isch & $U_{n k}^{a}$ & $2 / 19 / 04$ & $\begin{array}{l}\text { MRJR-W-16502 } \\
\text { MRJR-W-16503 } \\
\text { MRJR-W-16504 }\end{array}$ & $\begin{array}{l}\text { Sample } \\
\text { Replicate } \\
\text { Second replicate }\end{array}$ & $\begin{array}{l}N^{b} \\
\text { ND } \\
\text { ND }\end{array}$ & $\begin{array}{l}\text { ND } \\
\text { ND } \\
\text { ND }\end{array}$ \\
\hline MW1S & $11-51$ & $6 / 2 / 04$ & $\begin{array}{l}\text { MRMW1S-W-16461 } \\
\text { MRQCDU-W-16467 }\end{array}$ & $\begin{array}{l}\text { Sample } \\
\text { Replicate }\end{array}$ & $\begin{array}{l}19 \\
19\end{array}$ & $\begin{array}{l}0.9 \mathrm{Jc} \\
0.9 \mathrm{~J}\end{array}$ \\
\hline MW7S & $20-45$ & $6 / 3 / 04$ & $\begin{array}{l}\text { MRMW7S-W-16466 } \\
\text { MRMW7S-W-16466DUP }\end{array}$ & $\begin{array}{l}\text { Sample } \\
\text { Duplicate laboratory } \\
\text { analysis }\end{array}$ & $\begin{array}{l}18 \\
18\end{array}$ & $\begin{array}{l}\text { ND } \\
\text { ND }\end{array}$ \\
\hline Manning & Unk & $6 / 4 / 04$ & $\begin{array}{l}\text { MRPRIVCAI-W-16472 } \\
\text { MRQCDU-W-16473 }\end{array}$ & $\begin{array}{l}\text { Sample } \\
\text { Replicate }\end{array}$ & $\begin{array}{l}6.5 \\
4.6\end{array}$ & $\begin{array}{l}\text { ND } \\
\text { ND }\end{array}$ \\
\hline Allen & Unk & $8 / 27 / 04$ & $\begin{array}{l}\text { MRALLEN-W-16505 } \\
\text { MRQCDU-W-16506 }\end{array}$ & $\begin{array}{l}\text { Sample } \\
\text { Replicate }\end{array}$ & $\begin{array}{l}8.7 \\
8.4\end{array}$ & $\begin{array}{l}5.7 \\
5.4\end{array}$ \\
\hline
\end{tabular}

a Unk, unknown depth.

b ND, contaminant not detected.

c $J$, estimated concentration less than method quantitation limit of $1 \mu \mathrm{g} / \mathrm{L}$. 
Monitoring Well Installation and Sampling, Morrill, Kansas

TABLE E.5 Recovery of system-monitoring compounds in organic analysis of water samples at Envirosystems, Inc.

\begin{tabular}{|c|c|c|c|c|c|}
\hline \multirow[b]{2}{*}{ Sample } & \multirow[b]{2}{*}{$\begin{array}{c}\text { Analysis } \\
\text { Date }\end{array}$} & \multirow[b]{2}{*}{$\begin{array}{c}\text { Sample } \\
\text { Delivery } \\
\text { Group }\end{array}$} & \multicolumn{3}{|c|}{ Recovery ${ }^{\mathrm{a}}(\%)$} \\
\hline & & & Toluene- $d_{8}$ & $\begin{array}{l}\text { Bromofluoro- } \\
\text { benzene }\end{array}$ & $\begin{array}{l}\text { 1,2-Dichloro- } \\
\text { ethane-d }\end{array}$ \\
\hline MRMW1D-W-16458 & $6 / 11 / 04$ & 406152 & 99 & 93 & 93 \\
\hline MRMW3S-W-16462 & $6 / 11 / 04$ & 406152 & 101 & 94 & 97 \\
\hline MRMW7S-W-16466 & $6 / 11 / 04$ & 406152 & 100 & 92 & 94 \\
\hline MRPRIVSTON-W-16475 & $6 / 11 / 04$ & 406152 & 101 & 93 & 95 \\
\hline MR-TB-W-18000 & $6 / 11 / 04$ & 406152 & 100 & 94 & 94 \\
\hline MRMW7S-W-16466MS & $6 / 11 / 04$ & 406152 & 98 & 94 & 100 \\
\hline MRMW7S-W-16466MSD & $6 / 11 / 04$ & 406152 & 97 & 92 & 97 \\
\hline VBLKBM & $6 / 11 / 04$ & 406152 & 94 & 91 & 97 \\
\hline
\end{tabular}

a Quality control limits for recovery are as follows:

Analyte

Toluene- $\mathrm{d}_{8}$

Bromofluorobenzene

1,2-Dichloroethane- $d_{4}$
QC Limits (\%)

$88-110$

$86-115$

$76-114$ 
TABLE E.6 Recovery and relative percent difference values for spike/spike duplicate organic analyses of soil samples by Envirosystems, Inc., with CLP methodology.

\begin{tabular}{|c|c|c|c|c|c|c|c|c|c|}
\hline \multirow[b]{2}{*}{ Compound } & \multicolumn{4}{|c|}{ Concentration $(\mu \mathrm{g} / \mathrm{kg})$} & \multicolumn{3}{|c|}{ Recovery (\%) } & \multicolumn{2}{|c|}{ Difference (\%) } \\
\hline & Sample & $\begin{array}{l}\text { Spike } \\
\text { Added }\end{array}$ & $\begin{array}{c}\text { Spike } \\
\text { Analysis }\end{array}$ & $\begin{array}{l}\text { Duplicate } \\
\text { Analysis }\end{array}$ & $\begin{array}{c}\text { Spike } \\
\text { Analysis }\end{array}$ & $\begin{array}{c}\text { Duplicate } \\
\text { Analysis }\end{array}$ & QC Limit & RPD & QC Limit \\
\hline \multicolumn{10}{|c|}{ Spike/spike duplicate analysis of MRMW04-W-16418 with SDG 3101030-ARG172 } \\
\hline 1,1-Dichloroethene & 0 & 50 & 38 & 36 & 75 & 72 & $61-145$ & 4 & 14 \\
\hline Trichloroethene & 0 & 50 & 41 & 42 & 82 & 85 & $71-120$ & 4 & 14 \\
\hline Benzene & 0 & 50 & 45 & 45 & 89 & 90 & $76-127$ & 1 & 11 \\
\hline Toluene & 0 & 50 & 46 & 46 & 92 & 91 & $76-125$ & 1 & 13 \\
\hline Chlorobenzene & 0 & 50 & 47 & 48 & 95 & 95 & $75-130$ & 0 & 13 \\
\hline
\end{tabular}


TABLE E.7 Carbon tetrachloride and chloroform results for verification samples analyzed by the AGEM Laboratory and Envirosystems, Inc.

\begin{tabular}{|c|c|c|c|c|c|c|c|c|c|}
\hline \multirow[b]{2}{*}{ Location } & \multirow[b]{2}{*}{ Sample } & \multirow{2}{*}{$\begin{array}{l}\text { Depth } \\
\text { (ft BGL) }\end{array}$} & \multirow{2}{*}{$\begin{array}{c}\text { Sample } \\
\text { Date }\end{array}$} & \multicolumn{3}{|c|}{ Carbon Tetrachloride } & \multicolumn{3}{|c|}{ Chloroform } \\
\hline & & & & AGEM & EICS $^{a}$ & RPD & AGEM & EICS & RPD \\
\hline Stone & MRPRIVSTON-W-16475 & Unk ${ }^{b}-34$ & $6 / 4 / 04$ & 10 & 6 & 47 & $N D^{c}$ & ND & - \\
\hline MW1D & MRMW1D-W-16458 & $63-88$ & $6 / 2 / 04$ & ND & ND & - & ND & ND & - \\
\hline MW3S & MRMW3S-W-16462 & $18-48$ & $6 / 2 / 04$ & 110 & 87 & 23 & 3.2 & 3 & 5.2 \\
\hline MW7S & MRMW7S-W-16466 & $20-45$ & $6 / 3 / 04$ & 18 & 13 & 29 & ND & ND & - \\
\hline
\end{tabular}

a EICS, Envirosystems, Inc.

b Unk, unknown depth.

c ND, contaminant not detected at quantitation limits of $1 \mu \mathrm{g} / \mathrm{L}$ for Method 524.2 at the AGEM Laboratory and $5 \mu \mathrm{g} / \mathrm{L}$ for the CLP method at the Envirosystems, Inc., laboratory. 
TABLE E.8 Percent recovery of known analyte concentrations obtained during inorganic carbon analyses of quality control samples at Severn-Trent Laboratory.

\begin{tabular}{|c|c|c|c|c|c|c|}
\hline \multirow[b]{3}{*}{ Compound } & \multicolumn{3}{|c|}{ Laboratory Control Sample Analysis } & \multicolumn{2}{|c|}{ Duplicate Analysis } & \multirow{3}{*}{$\begin{array}{l}\text { RPD } \\
(\%)\end{array}$} \\
\hline & \multicolumn{2}{|c|}{ Concentration $(\mu \mathrm{g} / \mathrm{L})$} & \multirow{2}{*}{$\begin{array}{l}\text { Recovery } \\
\quad(\%)\end{array}$} & \multirow{2}{*}{$\begin{array}{c}\text { Detected } \\
\text { Concentration } \\
(\mu \mathrm{g} / \mathrm{L})\end{array}$} & \multirow{2}{*}{$\begin{array}{l}\text { Recoverya } \\
(\%)\end{array}$} & \\
\hline & Actual & Detected & & & & \\
\hline \multicolumn{7}{|l|}{ SDG 100080} \\
\hline Chloride & 5,000 & 5,200 & 104 & 5,200 & 104 & 0 \\
\hline Nitrate as $\mathrm{N}$ & 3,000 & 3,000 & 100 & 3,000 & 100 & 0 \\
\hline Phosphate & 2,000 & 2,300 & 115 & 2,300 & 115 & 0 \\
\hline Chloride & 5,000 & 5,500 & 110 & 5,500 & 110 & 3.7 \\
\hline Sulfate & 10,000 & 11,000 & 110 & 11,000 & 110 & 3.7 \\
\hline Nitrate as $\mathrm{N}$ & 3,000 & 3,100 & 103 & 3,100 & 103 & 0 \\
\hline Nitrite Nitrogen & 20 & 18 & 90 & 18 & 90 & 5.4 \\
\hline Nitrate/Nitrite $\mathrm{N}$ & 13,000 & 13,600 & 105 & 13,600 & 105 & 1 \\
\hline Nitrate/Nitrite N & 13,000 & 13,300 & 102 & 13,300 & 102 & 0 \\
\hline Aluminum & 51,000 & 48,680 & 95.5 & NA & NA & NA \\
\hline Calcium & 50,000 & 47,480 & 95 & NA & NA & NA \\
\hline Iron & 50,500 & 48,700 & 96.4 & NA & NA & NA \\
\hline Magnesium & 50,000 & 47,350 & 94.7 & NA & NA & NA \\
\hline Manganese & 500 & 467.1 & 93.4 & NA & NA & NA \\
\hline Phosphorus & 1,000 & 946.4 & 94.6 & NA & NA & NA \\
\hline Potassium & 50,000 & 46,490 & 93 & NA & NA & NA \\
\hline Silicon & 1,000 & 972.4 & 97.2 & NA & NA & NA \\
\hline Sodium & 50,000 & 47,770 & 95.5 & NA & NA & NA \\
\hline Zinc & 500 & 468.8 & 93.8 & NA & NA & NA \\
\hline \multicolumn{7}{|l|}{ SDG 100570} \\
\hline Chloride & 5,000 & 4,950 & 99 & 4,940 & 99 & 0 \\
\hline Nitrate as $\mathrm{N}$ & 3,000 & 2,820 & 94 & 2,870 & 96 & 2.1 \\
\hline Phosphate & 2,000 & 1,960 & 98 & 2,010 & 101 & 3 \\
\hline Sulfate & 10,000 & 8,870 & 89 & 8,910 & 89 & 0 \\
\hline Chloride & 5,000 & 4,680 & 94 & 4,870 & 97 & 3.1 \\
\hline Nitrate as $\mathrm{N}$ & 3,000 & 2,830 & 94 & 2,850 & 95 & 1.1 \\
\hline Nitrate as $\mathrm{N}$ & 3,000 & 2,880 & 96 & 2,870 & 96 & 0 \\
\hline Nitrite Nitrogen & 20 & 20.8 & 104 & 20.4 & 102 & 1.9 \\
\hline Nitrate/Nitrite N & 13,000 & 14,200 & 109 & 14,200 & 109 & 0 \\
\hline Nitrate/Nitrite N & 13,000 & 13,400 & 103 & 13,400 & 103 & 0 \\
\hline Aluminum & 51,000 & 47,480 & 93.1 & 46,120 & 90.4 & 2.9 \\
\hline Calcium & 50,000 & 46,370 & 92.7 & 45,100 & 90.2 & 2.7 \\
\hline Iron & 50,500 & 47,560 & 94.2 & 46,130 & 91.3 & 3.1 \\
\hline Magnesium & 50,000 & 47,880 & 95.8 & 47,390 & 94.8 & 1 \\
\hline Manganese & 500 & 469.1 & 93.8 & 455.3 & 91.1 & 2.9 \\
\hline Phosphorus & 1,000 & 913.5 & 91.4 & 876.7 & 87.7 & 4.1 \\
\hline Potassium & 50,000 & 46,300 & 92.6 & 45,110 & 90.2 & 2.6 \\
\hline Silicon & 1,000 & 1,002 & 100.2 & 984.5 & 98.4 & 1.8 \\
\hline Sodium & 50,000 & 47,930 & 95.9 & 46,990 & 94 & 2 \\
\hline Zinc & 500 & 451 & 90.2 & 438.5 & 87.7 & 2.8 \\
\hline
\end{tabular}


TABLE E.8 (Cont.)

\begin{tabular}{|c|c|c|c|c|c|c|}
\hline \multirow[b]{3}{*}{ Compound } & \multicolumn{3}{|c|}{ Laboratory Control Sample Analysis } & \multicolumn{2}{|c|}{ Duplicate Analysis } & \multirow{3}{*}{$\begin{array}{l}\text { RPD } \\
(\%)\end{array}$} \\
\hline & \multicolumn{2}{|c|}{ Concentration $(\mu \mathrm{g} / \mathrm{L})$} & \multirow{2}{*}{$\begin{array}{l}\text { Recoverya } \\
(\%)\end{array}$} & \multirow{2}{*}{$\begin{array}{c}\text { Detected } \\
\text { Concentration } \\
(\mu \mathrm{g} / \mathrm{L})\end{array}$} & \multirow{2}{*}{$\begin{array}{l}\text { Recoverya } \\
\text { (\%) }\end{array}$} & \\
\hline & Actual & Detected & & & & \\
\hline \multicolumn{7}{|l|}{ SDG 100606} \\
\hline Phosphate & 2,000 & 1,890 & 95 & 1,850 & 95 & 0 \\
\hline Chloride & 5,000 & 4,680 & 94 & 4,870 & 98 & 4.2 \\
\hline Sulfate & 10,000 & 9,690 & 97 & 10,700 & 107 & 9.8 \\
\hline Nitrate as $\mathrm{N}$ & 3,000 & 2,830 & 93 & 2,850 & 93 & 0 \\
\hline Chloride & 5,000 & 4,790 & 96 & 4,780 & 96 & 0 \\
\hline Nitrite Nitrogen & 20 & 20 & 100 & 20 & 100 & 0 \\
\hline Nitrate/Nitrite N & 13,000 & 14,200 & 109 & 14,200 & 109 & 0 \\
\hline Nitrate/Nitrite N & 13,000 & 13,400 & 103 & 13,400 & 103 & 0 \\
\hline Aluminum & 51,000 & 47,480 & 93.1 & 46,120 & 90.4 & 2.9 \\
\hline Calcium & 50,000 & 46,370 & 92.7 & 45,100 & 90.2 & 2.7 \\
\hline Iron & 50,500 & 47,560 & 94.2 & 46,130 & 91.3 & 3.1 \\
\hline Magnesium & 50,000 & 47,880 & 95.8 & 47,390 & 94.8 & 1 \\
\hline Manganese & 500 & 469.1 & 93.8 & 455.3 & 91.1 & 2.9 \\
\hline Phosphorus & 1,000 & 913.5 & 91.4 & 876.7 & 87.7 & 4.1 \\
\hline Potassium & 50,000 & 46,300 & 92.6 & 45,110 & 90.2 & 2.6 \\
\hline Silicon & 1,000 & 1,002 & 100.2 & 984.5 & 98.4 & 1.8 \\
\hline Sodium & 50,000 & 46,620 & 93.2 & 45,400 & 90.8 & 2.6 \\
\hline Zinc & 500 & 451 & 90.2 & & 87.7 & 2.8 \\
\hline \multicolumn{7}{|l|}{ SDG 100811} \\
\hline Chloride & 5,000 & 4,790 & 96 & 4,730 & 94 & 2.1 \\
\hline Phosphate & 2,000 & 2,270 & 115 & 2,340 & 115 & 0 \\
\hline Sulfate & 10,000 & 9,530 & 95 & 9,400 & 94 & 1.1 \\
\hline Nitrate as $\mathrm{N}$ & 3,000 & 2,690 & 90 & 2,710 & 90 & 0 \\
\hline Nitrite Nitrogen & 20 & 20.5 & 105 & 20.1 & 100 & 4.9 \\
\hline Nitrate/Nitrite N & 13,000 & 12,900 & 99 & NA & NA & NA \\
\hline Aluminum & 51,000 & 48,600 & 95.3 & 48,620 & 95.3 & 0 \\
\hline Calcium & 50,000 & 46,510 & 93 & 46,610 & 93.2 & 0.2 \\
\hline Iron & 50,500 & 47,330 & 93.7 & 47,360 & 93.8 & 0.1 \\
\hline Magnesium & 50,000 & 46,310 & 92.6 & 46,350 & 92.7 & 0.1 \\
\hline Manganese & 500 & 473.8 & 94.8 & 474.1 & 94.8 & 0 \\
\hline Phosphorus & 1,000 & 978.5 & 97.8 & 955.7 & 95.6 & 2.3 \\
\hline Potassium & 50,000 & 45,730 & 91.5 & 45,970 & 91.9 & 0.4 \\
\hline Silicon & 1,000 & 979.4 & 97.9 & 978.3 & 97.8 & 0.1 \\
\hline Sodium & 50,000 & 47,500 & 95 & 47,810 & 95.6 & 0.6 \\
\hline Zinc & 500 & 475.8 & 95.2 & 473.9 & 94.8 & 0.4 \\
\hline
\end{tabular}

a Recovery $=100 \times \frac{\text { detected concentration }}{\text { actual }}$ 
TABLE E.9 Relative percent difference in concentrations detected during inorganic analysis of samples and replicates at Severn Trent Laboratory.

\begin{tabular}{|c|c|c|c|c|c|c|c|c|c|}
\hline \multirow[b]{3}{*}{ Compound } & \multicolumn{3}{|c|}{ Moravec Well } & \multicolumn{3}{|c|}{ MW1S } & \multicolumn{3}{|c|}{ MW7S } \\
\hline & \multicolumn{2}{|c|}{ Concentration ( $\mu \mathrm{g} / \mathrm{L})$} & \multirow[b]{2}{*}{$\mathrm{RPD}^{\mathrm{a}}$} & \multicolumn{2}{|c|}{ Concentration $(\mu \mathrm{g} / \mathrm{L})$} & \multirow[b]{2}{*}{$\mathrm{RPD}^{\mathrm{a}}$} & \multicolumn{2}{|c|}{ Concentration $(\mu \mathrm{g} / \mathrm{L})$} & \multirow[b]{2}{*}{$\mathrm{RPD}^{2}$} \\
\hline & Sample & Replicate & & Sample & Replicate & & Sample & Replicate & \\
\hline Chloride & 6.3 & 6.23 & 1.1 & 84.6 & 73 & 14.7 & 15.6 & 15.7 & 0.6 \\
\hline Sulfate & 26.1 & 25.9 & 0.8 & 35.1 & 34.8 & 0.9 & 26.6 & 27.2 & 2.2 \\
\hline Nitrate as $\mathrm{N}$ & 18.2 & 18 & 1.1 & 11.2 & 10.4 & 7.4 & 17.3 & 17.4 & 0.6 \\
\hline Phosphate & $<0.2$ & $<0.2$ & - & $<0.2$ & $<0.2$ & - & 0.34 & 0.41 & 18.6 \\
\hline Nitrate/Nitrite N & 18.9 & 18.6 & 1.6 & 11.8 & 12.1 & 3 & 15.8 & 15.8 & 0 \\
\hline Nitrite Nitrogen & $<0.005$ & $<0.005$ & - & $<0.005$ & $<0.005$ & - & 0.012 & 0.009 & 28 \\
\hline Aluminum & $<0.2$ & $<0.2$ & - & $<0.2$ & $<0.2$ & - & $<0.2$ & $<0.2$ & - \\
\hline Calcium & 96.1 & 96.5 & 0.4 & 118 & 120 & 1.7 & 106 & 104 & 1.9 \\
\hline Iron & $<0.1$ & $<0.1$ & - & $<0.1$ & $<0.1$ & - & $<0.1$ & $<0.1$ & - \\
\hline Magnesium & 21.5 & 20.6 & 4.3 & 27.5 & 28.3 & 2.9 & 21.8 & 21.6 & 0.9 \\
\hline Manganese & $<0.015$ & $<0.015$ & - & $<0.015$ & $<0.015$ & - & $<0.015$ & $<0.015$ & - \\
\hline Phosphorus & $<0.25$ & $<0.25$ & - & $<0.25$ & $<0.25$ & - & $<0.25$ & $<0.25$ & - \\
\hline Potassium & $<5$ & $<5$ & - & $<5$ & $<5$ & - & $<5$ & $<5$ & - \\
\hline Silicon & 8.92 & 8.9 & 0.2 & 7.86 & 8.07 & 2.6 & 7.4 & 7.27 & 1.7 \\
\hline Sodium & 15.4 & 15.4 & 0 & 36.4 & 38.7 & 6.1 & 24.7 & 23.8 & 3.7 \\
\hline Zinc & 0.027 & 0.043 & 45 & $<0.02$ & $<0.02$ & - & $<0.02$ & $<0.02$ & - \\
\hline
\end{tabular}

a RPD, relative percent difference. 